\title{
Evaluation of the Changes of the Concentration, Composition and Possible Sources of Size-Resolved Particulate Matter between 2010 and 2011 in a Western Chinese Mega City
}

\author{
Yu-Fen Zhang ${ }^{1}$, Hong Xu ${ }^{1}$, Gui-Rong Liu ${ }^{1}$, Ying-Ze Tian ${ }^{1}$, Guo-Liang Shi ${ }^{{ }^{*}}$, Jian-Hui Wu ${ }^{1}$, \\ Pu Zhang ${ }^{2}$, Lai-Dong Zhou ${ }^{2}$, Yin-Chang Feng ${ }^{1 \dagger}$ \\ ${ }^{1}$ State Environmental Protection Key Laboratory of Urban Ambient Air Particulate Matter Pollution Prevention and \\ Control, College of Environmental Science and Engineering, Nankai University, Tianjin 300071, China \\ ${ }^{2}$ Chengdu Research Academy of Environmental Sciences, Chengdu 610041, China
}

\begin{abstract}
In this work, $\mathrm{PM}_{2.5}$ and $\mathrm{PM}_{10}$ samples were collected from four functional regions in Chengdu city from Jan. to Feb. in 2010 and 2011. The chemical concentrations of nineteen elements, two water-soluble ions and TC were measured. The results showed that the levels of particulates and their chemical components were relatively higher in 2010 than those in 2011: for $\mathrm{PM}_{10}, \mathrm{PM}(39 \%)$, Si (27\%), TC (76\%), $\mathrm{NO}_{3}{ }^{-}(16 \%), \mathrm{SO}_{4}{ }^{2-}(19 \%)$; for $\mathrm{PM}_{2.5}, \mathrm{PM}(33 \%), \mathrm{Si}(11 \%), \mathrm{TC}(67 \%)$, $\mathrm{NO}_{3}{ }^{-}(32 \%), \mathrm{SO}_{4}{ }^{2-}(17 \%)$. Ternary diagram analysis, enrichment and other statistical methods were employed to study the spatial and temporal variations of the concentrations of PM and their compositions. Moreover, relative changes (\%) of concentrations combined with the relative reported data from statistical yearbook and environmental quality reports are discussed to evaluate the effects of pollution control strategies for different functional regions. Finally, back-trajectory and factor-cluster analysis are proposed as an aid for the discussion of the meteorological influences and the possible source categories. The reduction of crustal dust may be attributed from the influence of long-range air transport. All the methods used above resulted in an overall agreement that showed the pollution control strategies were effective in reducing particulate air pollution: the total carbon (TC) reduction, accounting for 40-49\% $\left(\mathrm{PM}_{10}\right)$ and 35-48\% $\left(\mathrm{PM}_{2.5}\right)$, was mostly attributed to the strategy of banning high-emission yellow-tag vehicles, especially in commercial regions; the reduction of $\mathrm{SO}_{2}$ and $\mathrm{NO}_{\mathrm{x}}$ emissions had an impact on the sulphate $\left(17.03 \%\right.$ for $\mathrm{PM}_{10}$ and $15.37 \%$ for $\left.\mathrm{PM}_{2.5}\right)$ and nitrate $(12.48 \%$ for $\mathrm{PM}_{10}$ and $21.58 \%$ for $\mathrm{PM}_{2.5}$ ) decrease. The findings of this study can provide useful information for developing effective control strategies.
\end{abstract}

Keywords: $\mathrm{PM}_{10} ; \mathrm{PM}_{2.5}$; Control strategies; Enrichment; Factor-cluster analysis.

\section{INTRODUCTION}

Atmospheric particulate matter (PM), which has been studied by numerous researchers, is an important air pollutant in many large cities (Zheng et al., 2005; Moorhouse, 2007; Thurston et al., 2011; Niyobuhungiro and Blottnitz, 2013; Tian et al., 2013). A large amount of PM not only affects visibility and causes acidification but also has adverse effects on human health, such as increased respiratory and

\footnotetext{
* Corresponding author.

Tel.: +86 22 23503397; Fax: +86 2223503397

E-mail address: nksgl@hotmail.com

${ }^{\dagger}$ Corresponding author.

Tel.: +8622 23507962

E-mail address: fengyc@nankai.edu.cn
}

cardiovascular symptoms and diseases (Harrison and Yin, 2000; Tie et al., 2009; Cheng et al., 2012; Vernile et al., 2013). Moreover, some studies have showed that PM can change the radiation balance, and have important effect on climate change (Bellouin et al., 2005; Tiwari et al., 2012; Tahir et al., 2013).

Due to these adverse effects caused by PM, many countries have taken various measures to control particle pollution to drastically reduce PM levels (Zhao et al., 2006; Heinberg and Fridley, 2010; Shao et al., 2011; Wang and Hao, 2012). Therefore, to establish highly efficient measures for PM control and prevention, it is imperative to evaluate the effectiveness of these control strategies.

Some studies have focused on the evaluation of policy implementation (O'Ryan, 1996; Gianini et al., 2012; Li et $a l ., 2012)$. Such studies have shown that pollution control strategies can be effective in decreasing particulate pollution in urban air. Although most of these studies have already 
analysed the changes of PM concentrations under the influence of control measures, few studies have examined their chemical characteristics, especially those of sizeresolved PMs. What's more, the studies about different regions are quite limited. Because urban areas represent an assembly of different land use types and different source categories, investigation of the effectiveness of control strategies for various functional regions is necessary.

In this paper, in order to evaluate the effectiveness of control strategies, we have chosen the same time in two years and the same monitoring regions in Chengdu. The changes of the concentration, composition and possible sources of size-resolved particulate matter between 2010 and 2011 in four functional regions of Chengdu have been studied. To discuss the chemical characteristic of PMs, methods of enrichment (RE), relative change (RC), ternary plots and back-trajectory were employed. Additionally, a recently proposed factor-cluster analysis (FCA) method was applied to identify the possible sources in monitoring regions (Masiol et al., 2010, 2012). To the best of our knowledge, this is the first time FCA has been used to study both temporary and spatial variation simultaneously. Moreover, this study represents a first effort to investigate the effectiveness of control strategies for different land use types. The findings in this work can be used to provide effective measures that can greatly enhance PM environmental management for different functional regions.

\section{MATERIALS AND METHODS}

\section{Sampling Site Description}

Chengdu $\left(102^{\circ} 54^{\prime}-104^{\circ} 53^{\prime} \mathrm{E}, 30^{\circ} 05^{\prime}-31^{\circ} 26^{\prime} \mathrm{N}\right)$, the capital of Sichuan Province in southwest China, is one of the most important economic, transportation and communication centres in Western China. The population is more than 10 million, and its area is approximately $12121 \mathrm{~km}^{2}$. Chengdu was recently named one of the 13 emerging megacities or megalopolises in China in a July 2012 report by the Economist Intelligence Unit. Chengdu is located at the western edge of the Sichuan Basin and sits on the Chengdu Plain. The area has a monsoon-influenced humid subtropical climate, with distinct seasons accompanied by abundant rainfall and protection from both sweltering summers and freezing winters. The cities' favourable climate contributes to the development of agriculture and animal husbandry, making Chengdu a comfortable place for sustained human habitat as well as a suitable home for giant pandas.

\section{Ambient Sampling Method}

$\mathrm{PM}_{10}$ and $\mathrm{PM}_{2.5}$ samples were collected from four functional regions: Background, Commercial, Industrial and Residential, as shown in Fig. S1 (in the supplementary material). The four sampling sites were named BGY (Background), HBDL (Commercial), KJY (Industrial) and SWY (Residential). The samplers were located on the top of the buildings, and the heights of the building are 10-15 meters. Two sampling campaigns were conducted from Jan. to Feb. in 2010 and 2011. In this work, a total of 126 samples (57 in 2010, 69 in 2011) of $\mathrm{PM}_{10}$ and 128 (59 in 2010, 69 in 2011) of $\mathrm{PM}_{2.5}$ were obtained. The $\mathrm{PM}_{10}$ and $\mathrm{PM}_{2.5}$ samples were collected by filtration using a medium-volume air sampler (Wuhan Tianhong Intelligence Instrumentation Facility, TH150 Medium Volume Sampler), with the pump set at 100 $\mathrm{L} / \mathrm{min}$ and running continuously for $24 \mathrm{~h}$, from 8:00 am to 8:00 am on the next day. For both $\mathrm{PM}_{10}$ and $\mathrm{PM}_{2.5}$ at each site, two parallel samplers were used, one for polypropylene membrane filters and the other for quartz-fibre filters.

\section{Chemical Analysis}

Concentrations of nineteen elements, two water-soluble ions and TC (total carbon) were measured. Briefly, the elements (including $\mathrm{Na}, \mathrm{Mg}, \mathrm{Al}, \mathrm{Si}, \mathrm{K}, \mathrm{Ca}, \mathrm{Ti}, \mathrm{V}, \mathrm{Cr}, \mathrm{Mn}$, $\mathrm{Fe}, \mathrm{Co}, \mathrm{Ni}, \mathrm{Cu}, \mathrm{Zn}, \mathrm{As}, \mathrm{Cd}, \mathrm{Hg}$ and $\mathrm{Pb}$ ) were analysed by an Inductively Coupled Plasma (IRIS Intrepid II, Thermo Electron) spectrometer (Baldwin et al., 1994; Shi et al., 2012; Tian et al., 2013). Water-soluble ions, $\mathrm{NO}_{3}^{-}$and $\mathrm{SO}_{4}{ }^{2-}$, were detected by ion chromatography (DX-120, Dionex Ltd., USA) after extraction by an ultrasonic extraction system (AS3120, AutoScience). A clip in the shape of a circle (15 $\mathrm{mm}$ in diameter) from each quartz-fibre filter was used to measure TC following the IMPROVE thermal/optical reflectance (TOR) protocol implemented in DRI/OGC carbon analysers (Chow et al., 1993; Watson et al., 1994). A detailed description of sampling and chemical analyses was provided in our previous studies (Bi et al., 2006; Wu et al., 2009).

\section{RESULTS AND DISCUSSION}

\section{$\mathrm{PM}_{10}$ and $\mathrm{PM}_{2.5}$ Concentrations}

The concentrations of size-resolved PM and chemical species are listed in Table 1. In 2010, the average concentrations of $\mathrm{PM}_{10}$ and $\mathrm{PM}_{2.5}$ were found to be in the range of $193.64-331.17 \mu \mathrm{g} / \mathrm{m}^{3}$ and $140.01-198.50 \mu \mathrm{g} / \mathrm{m}^{3}$, respectively. In 2011, the average concentrations at four different functional regions varied from 134.29 to 231.85 $\mu \mathrm{g} / \mathrm{m}^{3}$ for $\mathrm{PM}_{10}$ and from 107.56 to $165.63 \mu \mathrm{g} / \mathrm{m}^{3}$ for $\mathrm{PM}_{2.5}$. The concentrations of $\mathrm{PM}_{10}$ and $\mathrm{PM}_{2.5}$ in 2011 were significantly lower than in 2010 , with a $\mathrm{p}$ value $<0.05$ (Ttest). Additionally, the concentrations of fine and coarse particulates in Chengdu were compared with those in other cities. As shown in Table S1 (in the supplementary material), it is obvious that the concentrations of the PMs in Chengdu were higher than in most of the other cities in the world (Park and Kim, 2005; Ho et al., 2006; Querol et al., 2008; Lim et al., 2010; Thurston et al., 2011; Murillo et al., 2012; Xu et al., 2012), though slightly lower than in some Chinese cities, such as Beijing (He et al., 2001; Wang et al., 2003; Zeng et al., 2010).

\section{Concentrations Variability in Different Regions}

The PM spatial distribution between 2010 and 2011 differed: in 2010, the $\mathrm{PM}_{10}$ concentration was highest in commercial regions and lowest in residential regions; in 2011, the $\mathrm{PM}_{10}$ concentration was highest in residential regions and lowest in commercial regions. Unlike $\mathrm{PM}_{10}$, the $\mathrm{PM}_{2.5}$ concentration exhibited the highest levels in industrial regions for both years. 


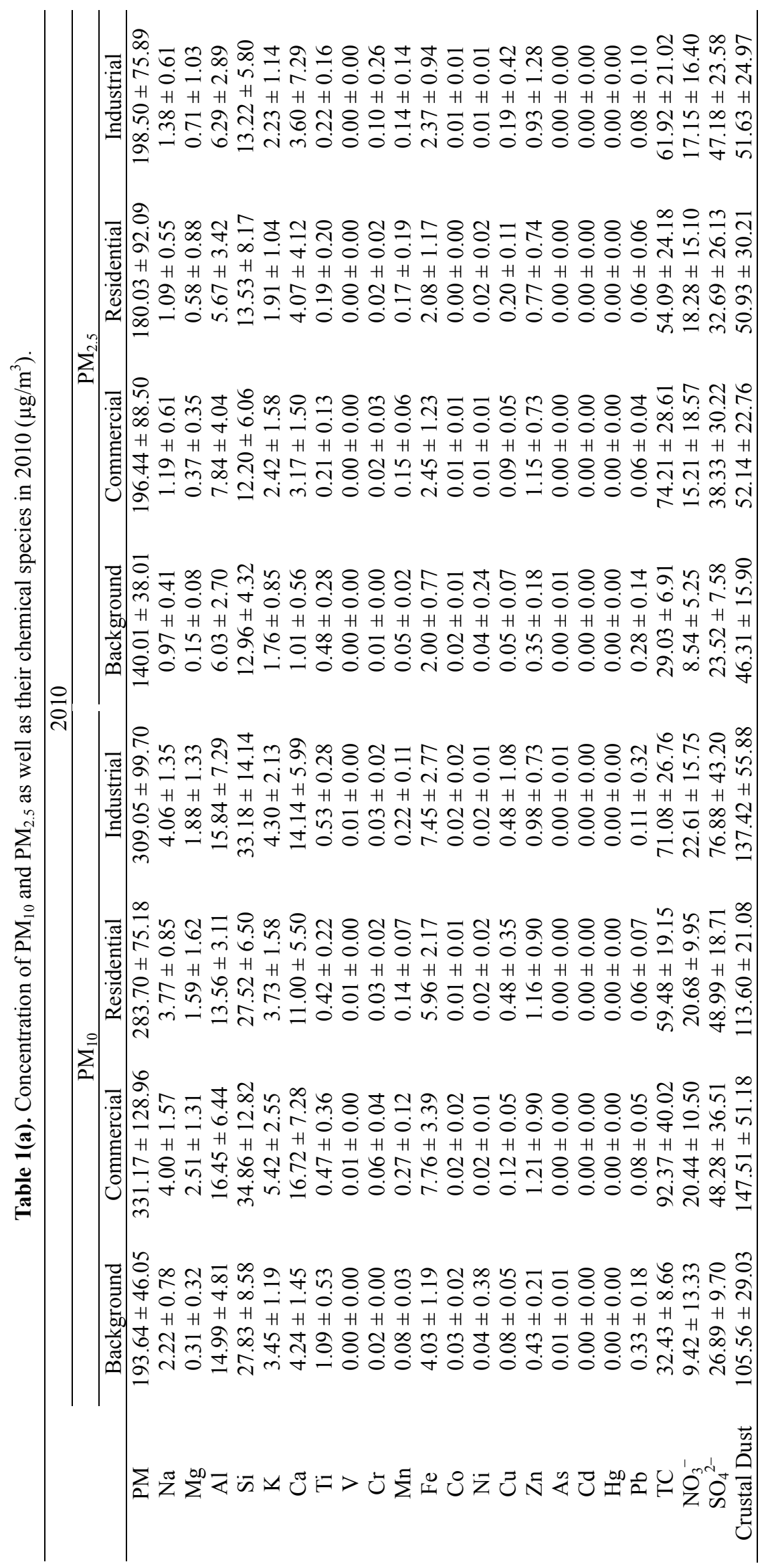




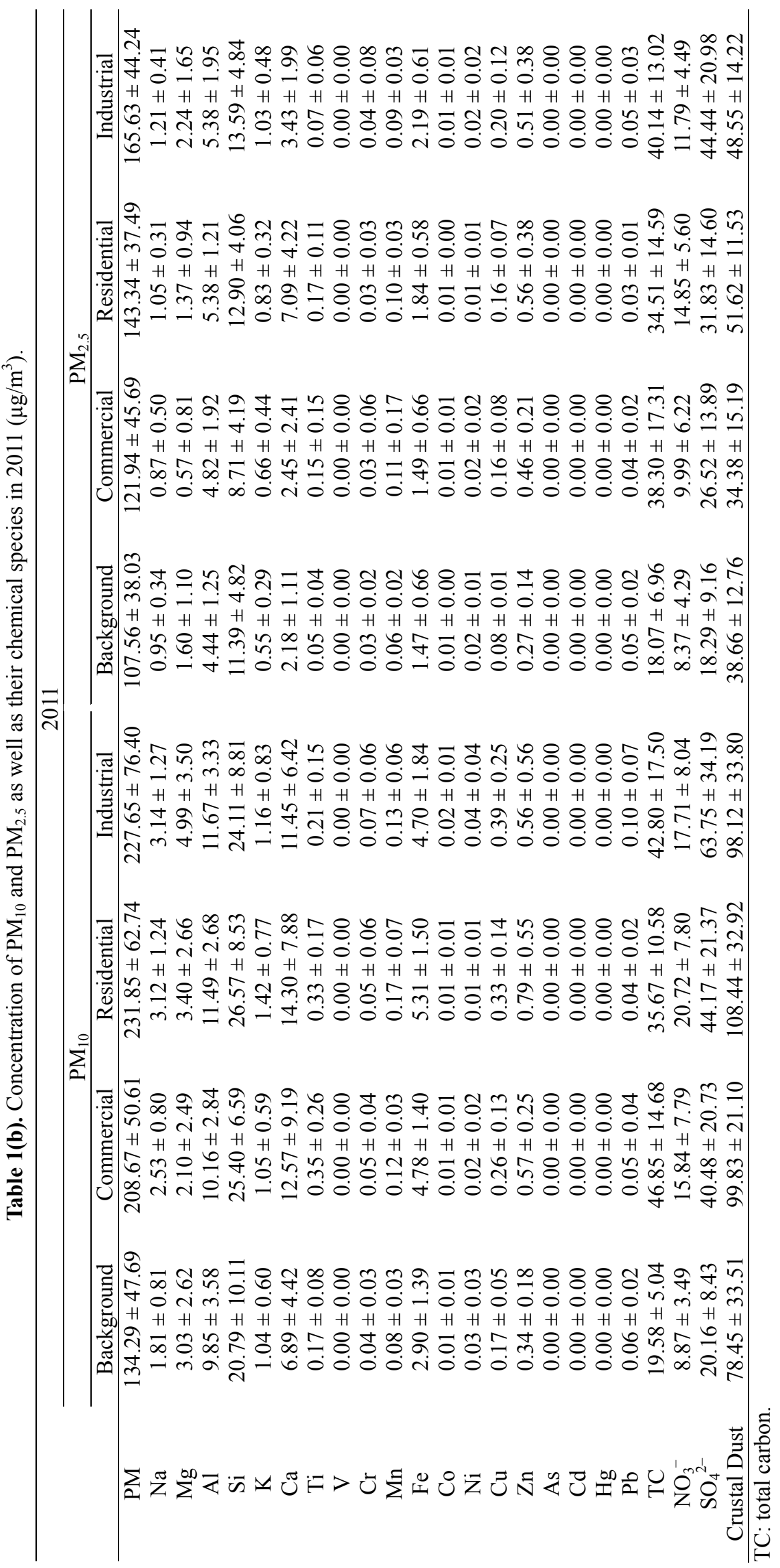


The concentrations and fractions of the chemical species collected at the four different functional regions in 2010 and 2011 are shown in Table 1 and Fig. S2. Similarly to other studies (Ho et al., 2006; Querol et al., 2008), carbonaceous species and secondary inorganic ions (sulphate, nitrate) (15-38\% and $19-36 \%$ of PMs) are the main contributors to the $\mathrm{PM}_{2.5}$ and $\mathrm{PM}_{10}$ concentrations. Other components, such as $\mathrm{Si}, \mathrm{Al}$ and $\mathrm{Ca}$, showed fractions of $6-15 \%, 3-8 \%$ and $1-$ $6 \%$ in the PMs, respectively.

The $\mathrm{PM}_{2.5} / \mathrm{PM}_{10}$ ratios for the concentrations of individual chemical species in the different functional regions are shown in Table S2, with a range from 0.58 to 0.80 . The ratio for TC was more than $80 \%$, due to most of the carbonaceous compositions mainly being enriched in fine PM (Wang et al., 2003). The $\mathrm{PM}_{2.5} / \mathrm{PM}_{10}$ ratios for nitrate and sulphate were relatively lower than $\mathrm{TC}$, at more than $60 \%$, due to $\mathrm{SO}_{4}{ }^{2-}$ and $\mathrm{NO}_{3}{ }^{-}$being more abundant in $\mathrm{PM}_{2.5}$ (Oh et al., 2011; Thurston et al., 2011; Wang et al., 2012). In contrast, crustal elements such as $\mathrm{Ca}, \mathrm{Mg}, \mathrm{Al}$ and $\mathrm{Na}$ appeared to have very low ratios of $\mathrm{PM}_{2.5} / \mathrm{PM}_{10}$. Studies have shown that the majority of crustal elements are likely to be enriched in coarse particulates (Querol et al., 2008). Overall, in each functional region, the size distribution of PM and chemical species showed similar characteristics (Gianini et al., 2012).

\section{Levels of Major Constituents in PM}

According to Table 1, chemical species such as Al, $\mathrm{Si}, \mathrm{Ca}$, $\mathrm{TC}, \mathrm{SO}_{4}{ }^{2-}$ and $\mathrm{NO}_{3}{ }^{-}$presented relatively high concentrations in all regions for both fine and coarse particles. Among these major constituents, $\mathrm{Al}, \mathrm{Si}$ and $\mathrm{Ca}$ are the markers of crustal dust (Shi et al., 2009; Begum et al., 2010; Shi et al., 2011), indicating crustal dust may contribute to the PM in these regions. Previous studies have shown that crustal dust can be estimated by the "sum of oxides" method (Andrews et al., 2000), assuming that the crustal dust is composed of $\mathrm{SiO}_{2}, \mathrm{Al}_{2} \mathrm{O}_{3}, \mathrm{Fe}_{2} \mathrm{O}_{3}, \mathrm{TiO}_{2}, \mathrm{CaO}$ and $\mathrm{K}_{2} \mathrm{O}$ (Hedberg et al., 2005). The concentration of crustal dust was calculated according to Hedberg et al. (2005):

$[$ Crustal dust $]=2.14[\mathrm{Si}]+1.89[\mathrm{Al}]+1.43[\mathrm{Fe}]+1.67[\mathrm{Ti}]$ $+1.40[\mathrm{Ca}]+1.20[\mathrm{~K}]$

where the square brackets are the concentrations of chemical species. The concentrations of crustal dust for all regions are also listed in Table 1.

Fig. 1 describes the fractions of major constituents for both PMs from all regions. Crustal dust exhibited the highest levels among the major constituents, accounting for 40-55\% (in 2010) and 43-58\% (in 2011) in $\mathrm{PM}_{10}$ and 26$33 \%$ (in 2010) and 28-36\% (in 2011) in $\mathrm{PM}_{2.5}$. These levels suggest that crustal dust may be an important source category in the study regions. TC, a marker of vehicle exhaust (Pant and Harrison, 2012), showed the second most abundant levels, indicating that vehicle exhaust may be a potential source category. The fractions of $\mathrm{SO}_{4}{ }^{2-}$ and $\mathrm{NO}_{3}{ }^{-}$were approximately $20 \%$ and $10 \%$, respectively, indicating that the secondary sulphate and nitrate may occur. Additionally, $\mathrm{SO}_{4}{ }^{2-}$ has also been reported to be a good marker for coal combustion (Pant and Harrison, 2012) due to its precursor gas $\left(\mathrm{SO}_{2}\right)$ being emitted from fossil fuel combustion (Shon et al., 2012). Thus, industrial coal combustion cannot be ignored. The annual total industrial coal consumption (million tons) and $\mathrm{SO}_{2}$ emission in Chengdu during 2010 and 2011 can be found in Table S3 in the supplementary material.

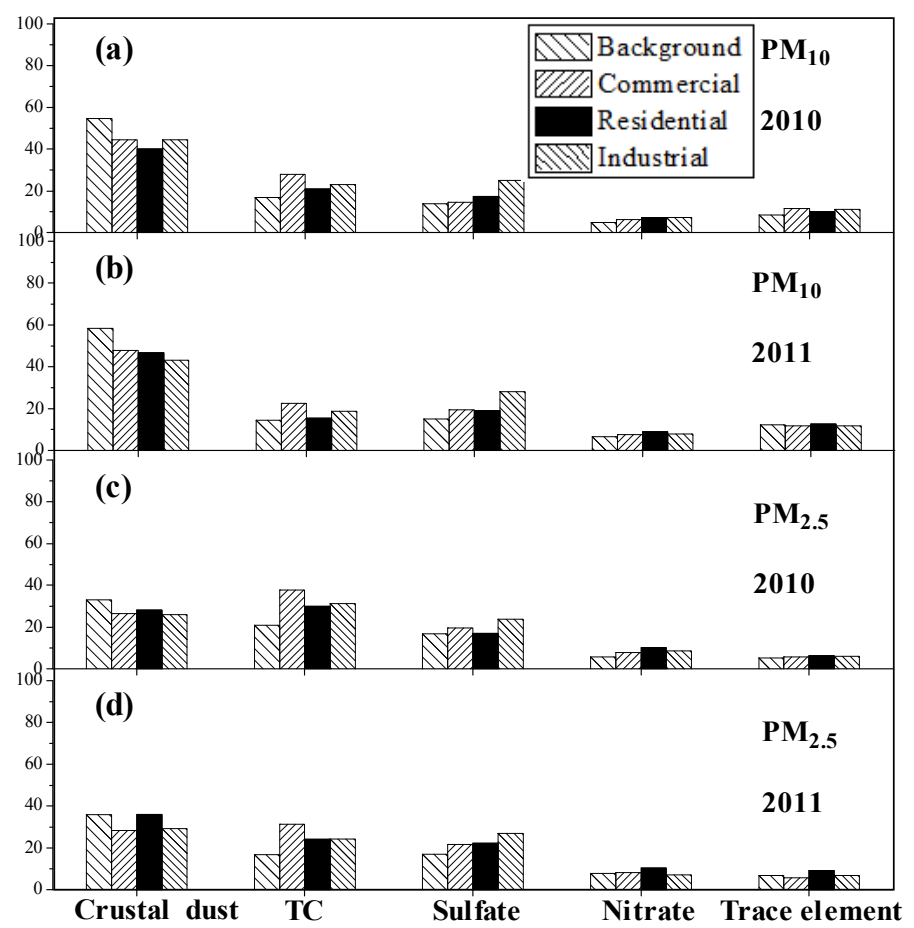

Fig. 1. Fractions (\%) of major constituents in size resolved PM from different regions, in 2010 and 2011. 
The fractions of major constituents in ambient PM are influenced by the profile of the source category. To analyse the fractions of major constituents, the ternary diagrams (in Fig. S3) for the fractions (\%) of crustal dust, TC and sulphate + nitrate are plotted. For $\mathrm{PM}_{10}$ in 2010 , it can be found that the points of the commercial regions exhibit relatively higher fractions $(\%)$ of $\mathrm{TC}$, indicating a more frequent impact of traffic in commercial regions than in other regions, which is reasonable due to the high traffic density present in the commercial regions. The points of the industrial regions were characterised by sulphate + nitrate, which suggested that secondary sources and industrial coal combustion might be the important sources categories in this region. For the background points, crustal dust was the richest component, as indicated by lack of the anthropologic sources. The possible sources for the residential regions were complex because of the lack of outstanding constituents. In 2011, $\mathrm{PM}_{10}$ exhibited a similar plot. However, the fractions of TC were clearly decreased for all the points, suggesting the influence of vehicle exhaust may have been relatively weaker in 2011 than in 2010.

The ternary diagrams of $\mathrm{PM}_{2.5}$ are consistent with those of $\mathrm{PM}_{10}$ in some aspects. Nevertheless, in comparison with the $\mathrm{PM}_{10}$ points, the fractions of TC and sulphate+nitrate in $\mathrm{PM}_{2.5}$ were relatively higher, while those of crustal dust in $\mathrm{PM}_{2.5}$ were lower. This result is due to crustal dust usually having a more pronounced coarse particle size fraction than coal combustion, vehicle emissions and other particles (Ehrlich et al., 2007; Lin et al., 2010), while $\mathrm{NO}_{3}{ }^{-}$and $\mathrm{SO}_{4}{ }^{2-}$ are rich in the fine particles (Lin et al., 2010; Zhang et al., 2011).

\section{Enrichment of Major Constituents for Different Regions}

As discussed above, the different regions are characterised by discriminative constituents. In this section, therefore, the enrichment of major constituents is calculated to further analyse the temporal and spatial variations of the chemical characteristics of PM. For the commercial region, the enrichment (RE) was calculated as follows (Gianini et al., 2012):

$$
\begin{aligned}
& \mathrm{RE}_{\mathrm{i}} \\
& 100
\end{aligned}=\left([\text { Commercial }]_{\mathrm{i}}-[\text { Background }]_{\mathrm{i}}\right) /[\text { Commercial }]_{\mathrm{i}} \times
$$

where $[\text { Commercial }]_{\mathrm{i}}$ and $[\text { Background }]_{\mathrm{i}}$ are the average concentrations $\left(\mu \mathrm{g} / \mathrm{m}^{3}\right)$ of the ith measured constituents in the commercial and background regions. For calculations of residential and industrial REs, [Commercial $]_{\mathrm{i}}$ in Eq. (2) should be replaced by [Residential $]_{\mathrm{i}}$ and [Industrial $]_{\mathrm{i}}$, respectively.

The temporal and spatial REs of size resolved PM and their major constituents are described in Fig. 2. It can be clearly found that the TC-REs presented the highest level for the commercial regions; sulphate-REs were important for the industrial regions; nitrate-REs were prominent for the residential regions; and the crustal dust-REs were quite low for all regions. The spatial variations of the REs may be attributable to the different important source categories in the different regions.
To further discuss the spatial differences of the REs, RE diagrams were made, which are scatter plots of the major constituent RE values for one region against those of another (Wongphatarakul et al., 1998; Zhang and Friedlander, 2000; Gianini et al., 2012). Fig. 3 gives a comprehensive comparison of the REs for all regions. According to all the scatter plots in Fig. 3, for both $\mathrm{PM}_{10}$ and $\mathrm{PM}_{2.5}$, it can be concluded that $\mathrm{TC}$ was higher in the commercial region than the other regions; sulphate was outstanding in the industrial regions; and for the residential regions, the prominent constituents were inconsistent for all the plots. The results of Fig. 3 are in reasonable agreement with those of the ternary diagram (in Fig. S3).

\section{The Changes of Chemical Concentrations}

Several studies have shown that pollution control strategies can positively affect atmospheric pollution reduction (Wang et al., 2009; Gianini et al., 2012). In this work, the changes of chemical concentrations between 2010 and 2011, combined with the relevant reported data in the Chengdu Statistical Yearbook and Chengdu Environmental Quality Reports (see Table S3), are discussed to evaluate the effects of pollution control strategies (Table S4). The relative changes (RCs) of the individual major constituents of PM are calculated according to:

$\operatorname{RC}(\%)=\left([2011]_{\mathrm{i}}-[2010]_{\mathrm{i}}\right) /[2010]_{\mathrm{i}} \times 100$

where $[2011]_{\mathrm{i}}$ and $[2010]_{\mathrm{i}}$ are the average concentrations $\left(\mu \mathrm{g} / \mathrm{m}^{3}\right)$ of the ith measured constituents in different sampling years. Fig. 4 describes the relative changes of the concentrations of $\mathrm{PM}_{10}$ and $\mathrm{PM}_{2.5}$ as well as their major constituents in 2010 and 2011 for the background, commercial, industrial and residential regions.

The mass concentrations of $\mathrm{PM}_{10}$ and $\mathrm{PM}_{2.5}$ were obviously reduced for all the regions, accounting for $18-37 \%\left(\mathrm{PM}_{10}\right)$ and $17-38 \%\left(\mathrm{PM}_{2.5}\right)$. Additionally, the major constituents exhibited various changes. First, the largest decrease was found for TC, accounting for 40-49\% $\left(\mathrm{PM}_{10}\right)$ and 35-48\% $\left(\mathrm{PM}_{2.5}\right)$. According to the Chengdu Statistical Yearbook (Table S3), the vehicle population increased from 2.36 (2010) to 2.59 (2011) million, which contradicts the results indicating the high reduction of TC. Hence, the positive change of TC is certainly attributable to the pollution control strategies (Strategy 2 in Table S4). As shown in Table S4, high-emission yellow-tag vehicles have been banned from roads (from 7:30 to 19:30) in urban areas since 1 Oct. 2010. According to Fig. 4, the relative changes of TC presented the highest level in the commercial regions, showing the most outstanding effect of strategy 2 in these regions compared with the other regions.

Second, the concentrations of sulphate and nitrate decreased in most regions. The implementation of the continuing reduction of $\mathrm{SO}_{2}$ (the precursor of sulphate) emissions might be an important factor for the reduction of sulphate (Strategy 1 in Table S4). During the Chinese Eleventh Fiveyear period (2006-2010), the continuing reduction of $\mathrm{SO}_{2}$ emissions was an important pollution control strategy in Chinese cities, and it played a key role in decreasing these 


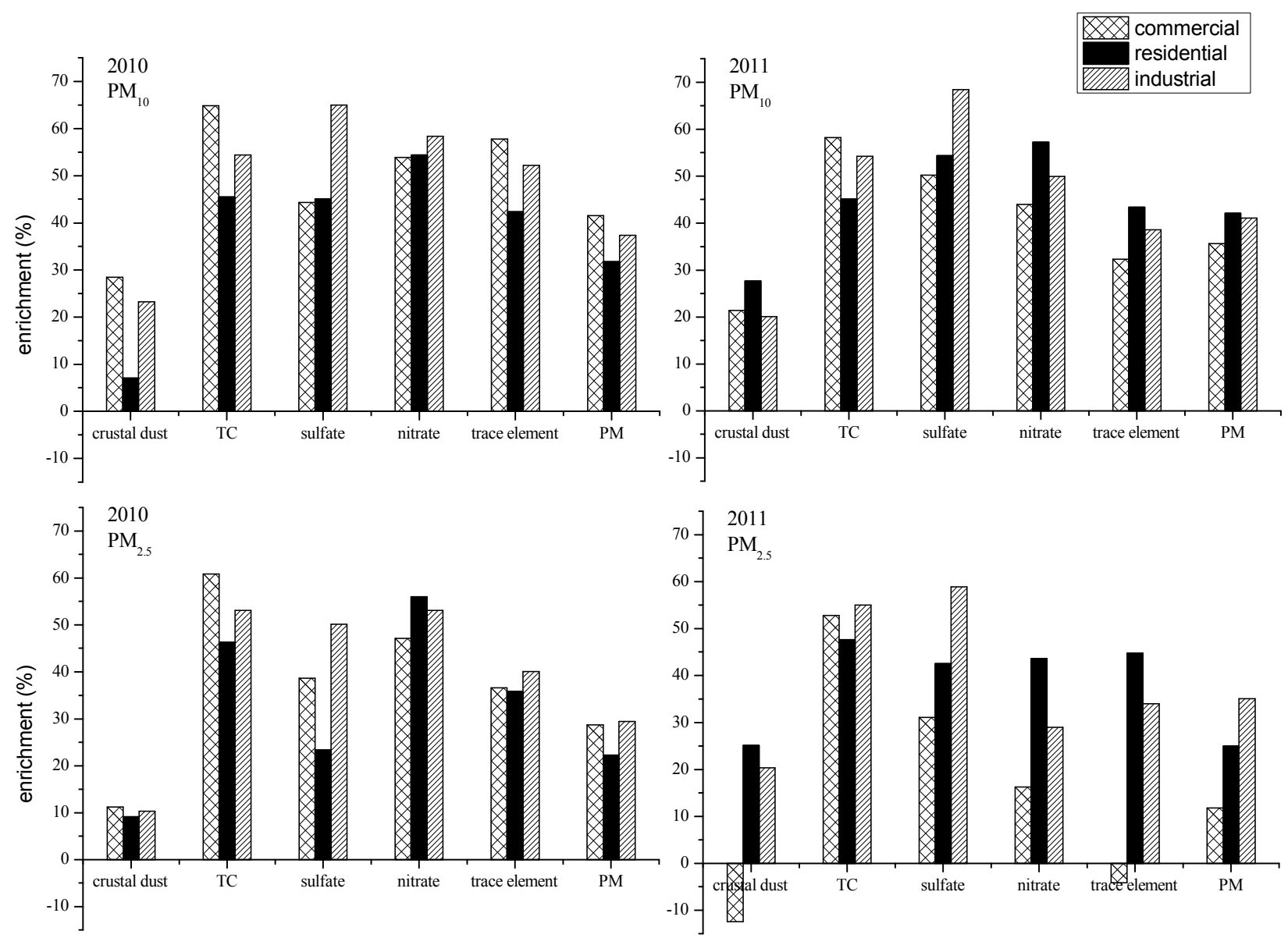

Fig. 2. Temporal and spatial REs (\%) of size resolved PM and their major constituents.

emissions. According to Table S3, the annual total industrial $\mathrm{SO}_{2}$ emissions decreased from 127 to 96.8 thousand tons (the relative change was $-24 \%$ ), and the industrial coal consumption ranged from 8690 to 7957 thousand tons (the relative change was $-8 \%$ ). Additionally, $\mathrm{SO}_{4}{ }^{2-}$ can also be product from the long-term transport. So the variety of transport in different years might be another factor for sulfate variation in the city. The $\mathrm{NO}_{\mathrm{x}}$ (the precursor of nitrate (Shon et al., 2012)) reduction may have been a chief influencing factor in the nitrate reduction. In Table S3, the annual total industrial $\mathrm{NO}_{\mathrm{x}}$ emissions decreased from 57.8 to 52.4 thousand tons. The yellow-tag vehicle ban also resulted in reduced $\mathrm{NO}_{\mathrm{x}}$ emissions.

Third, for most regions the concentrations of crustal dust decreased obviously. As found in some studies, long-range air transport usually contributes to crustal dust in addition to local pollution (Wang and Hao, 2012). To better understand the air flow and long-range transport patterns, the back trajectory model was applied. 3-D 72-hour back trajectories were calculated using the NOAA Hybrid Single Particle Lagrangian Integrated Trajectory (HYSPLIT-4.9) model from 1 Jan. to 28 Feb. in 2010 and 2011, respectively. For each day, the 3D 72-h backward trajectories were calculated every $6 \mathrm{~h}$ at $08,14,20$, and 02 UTC (coordinated universal time) at a height of $500 \mathrm{~m}$ above the ground level (Hwang and Hopke, 2007). A total of 236 trajectories were calculated and inputted for cluster analysis to identify the common atmospheric transport patterns. As shown in Fig. S4(a) and S4(b), six clusters were obtained according to their overall wind speed and direction for each year. Note that in the cluster map for 2010, Cluster $1(13 \%)$ came from the direction of Xinjiang province. It is well known that the Taklimakan Desert (the largest desert in China) is in the southwest portion of Xinjiang province. In 2011, the trajectories (Cluster 1) originating from Xinjiang province were only $3 \%$ of the total trajectories, much lower than those in 2010 ; and the cluster from the Inner Mongolia province only accounted for $5 \%$. Thus, the changes of crustal dust may be attributable from the influence of long-range air transport.

\section{Source Identification by FCA}

As discussed above, the spatial and temporal variations of the major constituents were attributed to the important source categories at the different regions in the two years. In this work, factor-cluster analysis (FCA) was performed to identify the potential source categories and then select groups of samples on the basis of their similar chemical compositions and origins (Masiol et al., 2010). The FCA included two steps. First, the ambient PM data were analysed by FA (factor analysis). The possible source categories were identified by the varimax rotated factor loading matrix. Factor scores (n samples and $\mathrm{p}$ extracted factors) associated 
with each sample were also obtained by FA. Second, the factor score matrix was applied as input for cluster analysis (CA) to group samples by similarity in source contributions
(Masiol et al., 2010). In recent studies, FCA had been proposed and proved as a useful tool for source identification (Masiol et al., 2010, 2012).
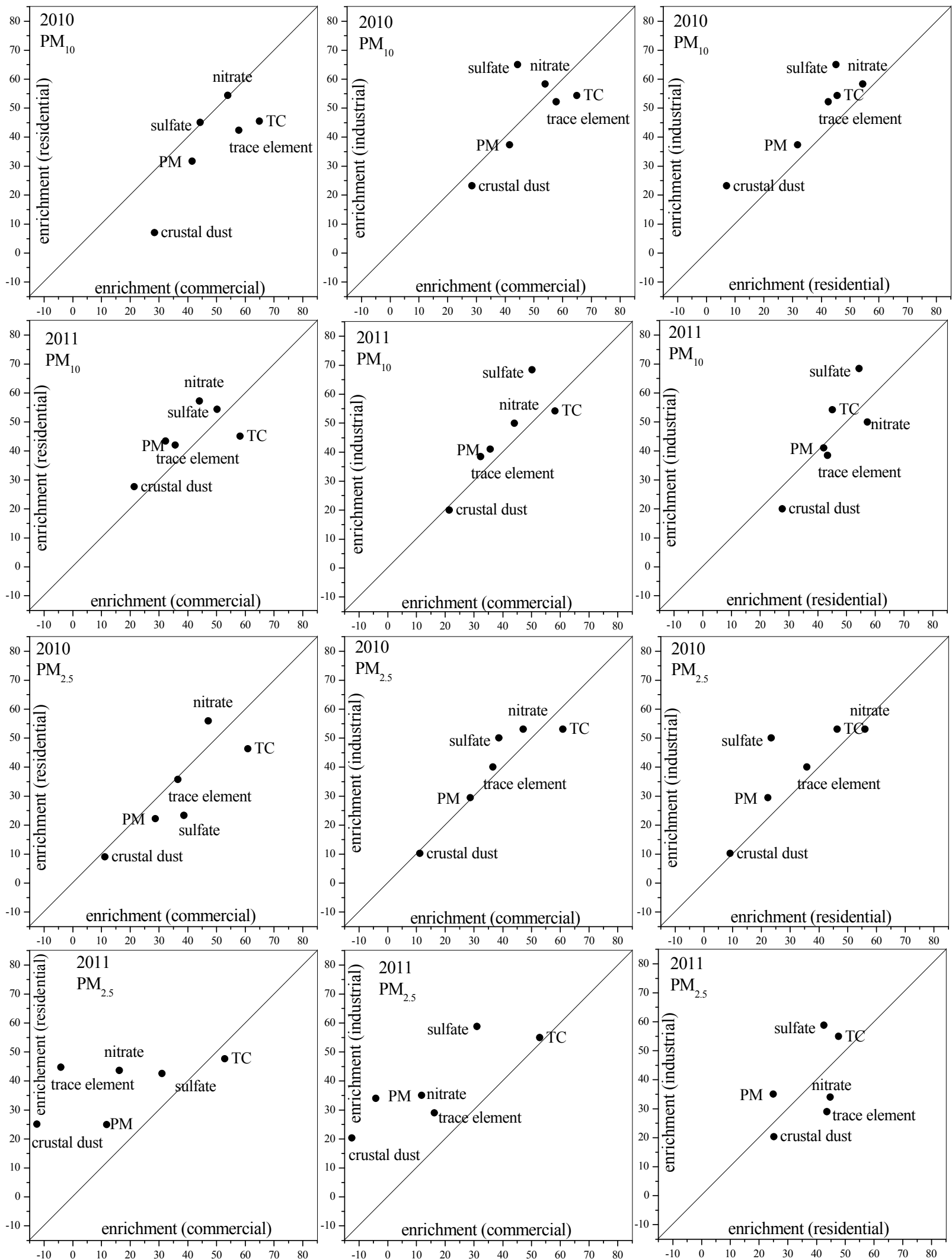

Fig. 3. Enrichment diagrams: region against region, for $\mathrm{PM}_{10}$ and $\mathrm{PM}_{2.5}$, in 2010 and 2011. 


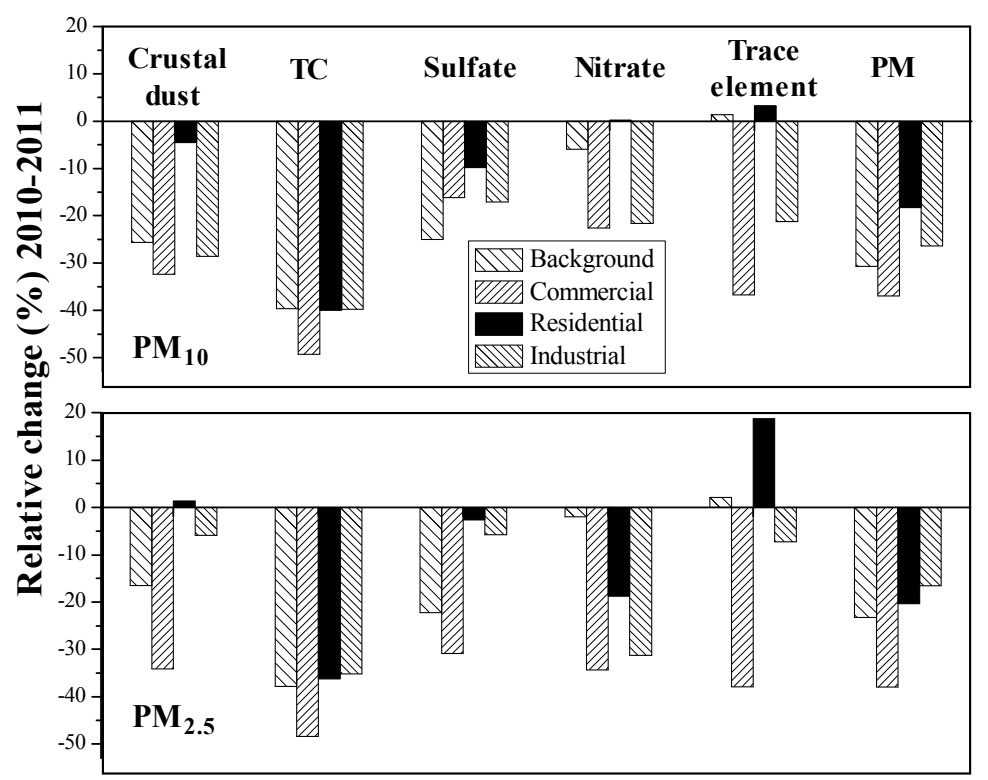

Fig. 4. Relative change (\%) for mean concentration of major constituents between the 2010 and 2011.

In this work, for the each size-resolved PM, the samples from all regions in the two years were combined to be used as input data for the FA. Amato and Hopke (2012) suggested that it is possible to use the spatial variability of the source contributions to enhance the source apportionment. In our previous and other works, using combined data for the factor model also produced reasonable results (Escrig et al., 2009; Shi et al., 2009). Thus, for $\mathrm{PM}_{10}$, a $126 \times 12$ input dataset was analysed by FA, where 126 is the number of $\mathrm{PM}_{10}$ samples and 12 is the number of chemical species (some trace elements were removed to avoid disturbance). SPSS 12.0 software was applied for the FA.

Table 2 lists the rotated factor loadings for the $\mathrm{PM}_{10}$ samples. Four factors were extracted by FA. The first factor ( $49 \%$ of the total variance) obtained high loadings for $\mathrm{Si}$, $\mathrm{Al}, \mathrm{Fe}$ and $\mathrm{TC}$. Si and $\mathrm{Al}$ are the source markers for crustal dust, and TC is associated with the vehicle exhaust emission. Thus, this factor may indicate mixed sources, including crustal dust and steel manufacture and vehicle exhaust emissions. The result of these sources being combined into a single factor most likely reflects the contribution of some regions with the influence of these sources, and therefore, FA cannot separate them (Minguillon et al., 2012). Factor 2 (16\% of the total variance) strongly correlated with $\mathrm{Ca}$ and can be identified as cement dust (Morishita et al., 2011). According to the field survey, cement manufactories located in the study areas, and this is in agreement with the identified source category. Additionally, Mg also got high loading, so the Magnesium alloy industrial manufacture source might be included in this factor. Factor 3 (10\% of the total variance) and Factor 4 ( $9 \%$ of the total variance) were weighted by $\mathrm{SO}_{4}{ }^{2-}$ and $\mathrm{NO}_{3}^{-}$, so the two factors can be identified as secondary sulphate and nitrate, respectively.

After FA, the factor scores were used as input for CA using Ward's method and Euclidean distance (Masiol et al., 2010). As shown in Fig. 5, five groups were clustered by FCA. The concentrations (mean \pm standard deviation) of
$\mathrm{PM}_{10}$ and the individual chemical species for each group are listed in Table 2 Group $1(\mathrm{n}=19)$, with high concentrations of $\mathrm{Al}, \mathrm{Si}, \mathrm{Fe}$ and $\mathrm{TC}$, can be associated with Factor 1. Group $2(\mathrm{n}=24)$ showed high fraction $(\%)$ of Ca compared with other factors, which can be interpreted as cement dust (Factor 2). Group $3(\mathrm{n}=15)$ and Group $4(\mathrm{n}=33)$ had high concentrations of $\mathrm{SO}_{4}{ }^{2-}$ and $\mathrm{NO}_{3}{ }^{-}$, which can be related to secondary sulphate (Factor 3 ) and secondary nitrate (Factor 4). Group 5 had no prominent high-level chemical species, might be the unknown sources. The FA explains $84 \%$ of the total variance of the $\mathrm{PM}_{10}$ dataset, so the residual $16 \%$ may be represented by Group 5, which in turn may be interpreted as background pollution.

Additionally, the results of FCA can show the source changes between 2010 and 2011 for the different regions. The samples clustered in Group 1 were mostly from the commercial and residential regions in 2010, while those in Group 2 were from the commercial and residential regions in 2011, showing the changes of the important source categories between the two years. These changes may be due to the yellow-tag vehicles being banned from the road and to building construction at the commercial and residential regions in 2011. For Group 2, most of the samples were from industrial regions in 2010 and 2011, indicating that the important source categories may not vary in industrial regions. The samples belonging to Group 4 were relatively complex, including the commercial, residential and industrial regions in 2010 and 2011. The emitted precursor gas $\mathrm{NO}_{\mathrm{x}}$ may influence the samples in Group 4. For Group 5, samples from the background and residential regions were included.

The results of the FCA for $\mathrm{PM}_{2.5}$ are shown in Table 3. Three factors were identified by FA. The first factor $(39 \%$ of the total variance), with a high loading of $\mathrm{Al}, \mathrm{Si}, \mathrm{Fe}, \mathrm{TC}$ and $\mathrm{NO}_{3}^{-}$, can be explained as mixed sources, including crustal dust, vehicle exhaust and secondary nitrate. The second factor ( $20 \%$ of the total variance) can be associated with secondary sulphate due to the high level of $\mathrm{SO}_{4}{ }^{2-}$, and 

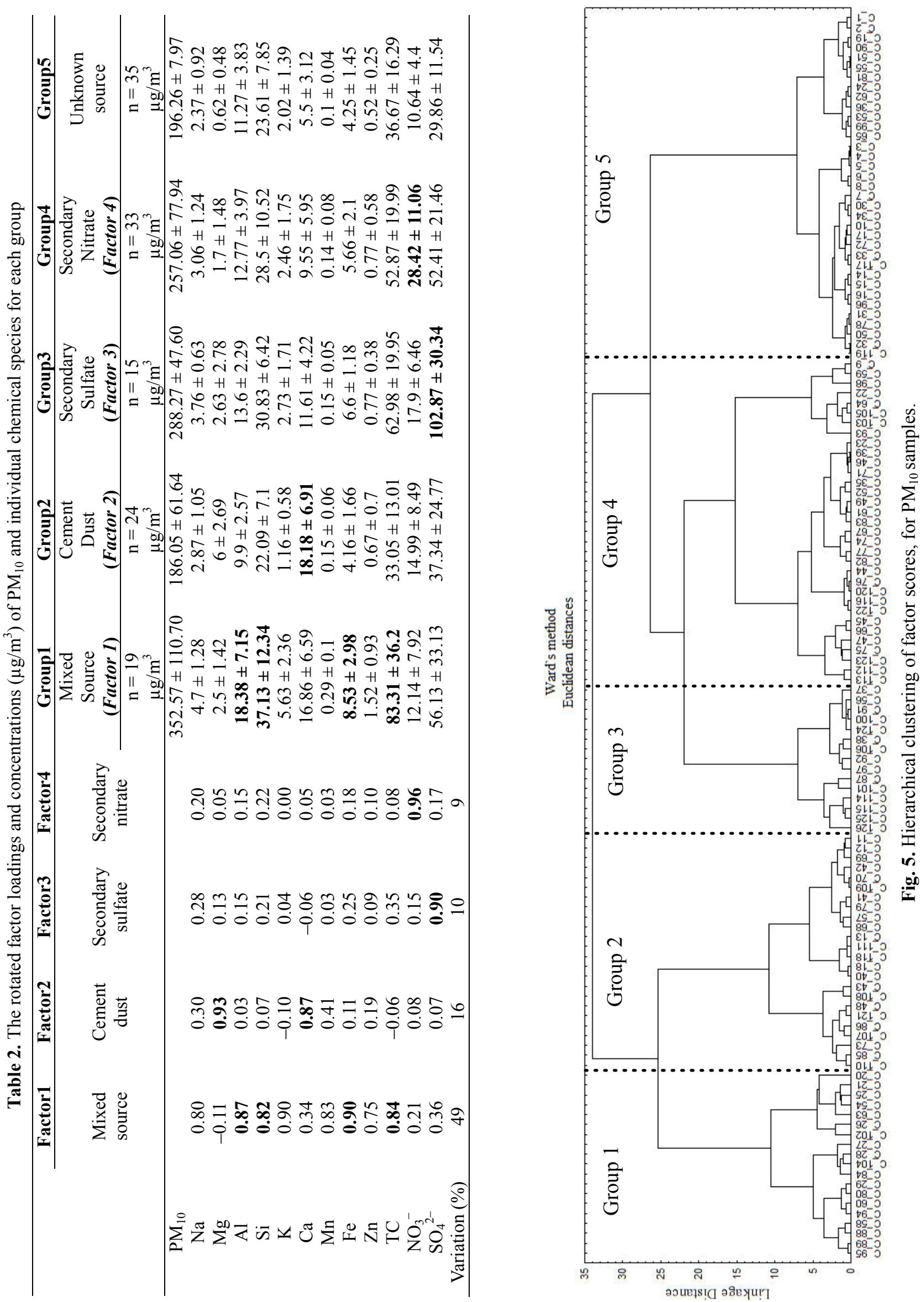


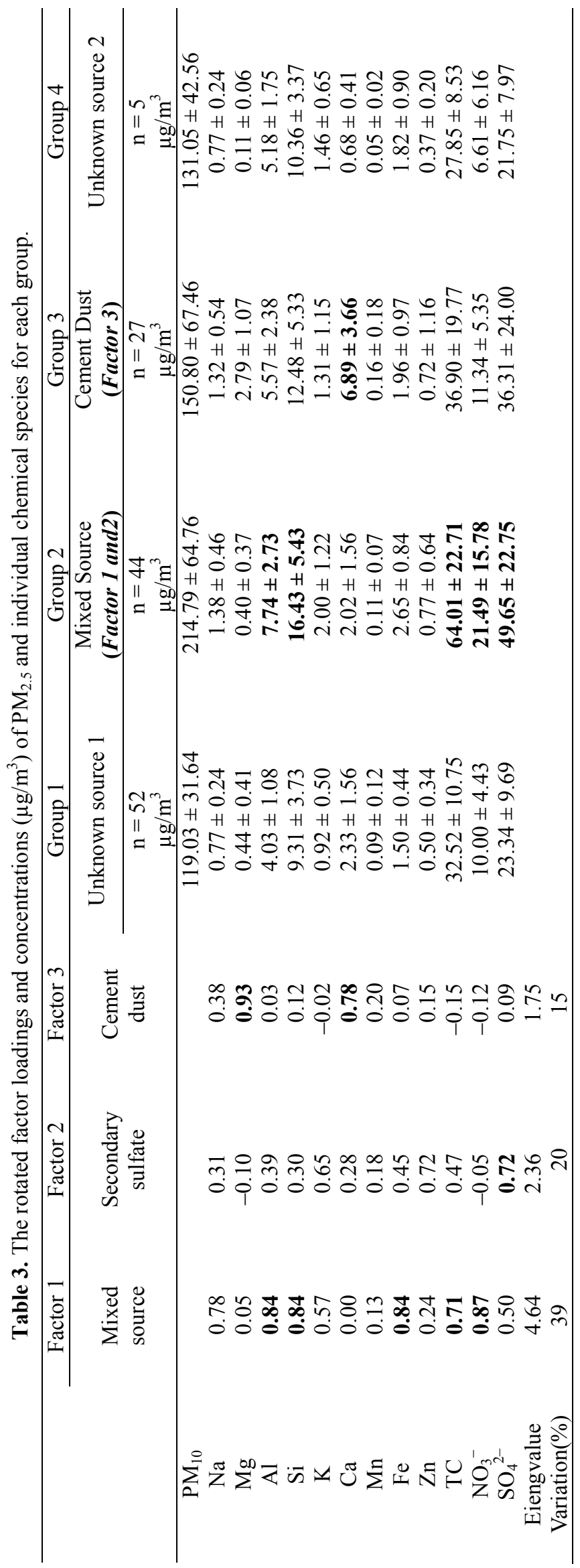


the third factor ( $15 \%$ of the total variance) may be the cement dust, as indicated by the high level of Ca. Additionally, similar to the results of $\mathrm{PM}_{10}$, Magnesium alloy industrial manufacture source might be included in this factor. Four groups were discriminated by FCA, as shown in Fig. 6. The concentration of $\mathrm{PM}_{2.5}$ and the individual chemical species for each group were calculated accordingly and are listed in Table 3. According to Table 3, Groups 1 and 4 may be explained as background pollution due to the lack of outstanding species; So Group 1 and Group 4 might be unknown sources. Group 2, with high fractions (\%) of $\mathrm{Al}$, $\mathrm{Si}, \mathrm{Fe}, \mathrm{TC}, \mathrm{NO}_{3}{ }^{-}$and $\mathrm{SO}_{4}{ }^{2-}$, may be a mixture of factors 1 and 2; and Group 3 may be related to factor 3 due to high concentration of $\mathrm{Ca}$. Concerning the origins of the samples included in each group, the samples in Group 1 were from the commercial and residential regions in 2010 and 2011 as well as the background in 2011; the samples in Group 2 were mainly from the commercial and residential regions in 2010 as well as the industrial regions in 2010 and 2011; the samples in Group 3 were from the commercial and residential regions in 2011; and the samples in Group 4 were from the background in 2010. Overall, the result of $\mathrm{PM}_{2.5}$ was similar to that of $\mathrm{PM}_{10}$ for $\mathrm{FCA}$, and the conclusions drawn from the FCA are in agreement with the discussion above.

\section{CONCLUSIONS}

In this study, $\mathrm{PM}_{10}$ and $\mathrm{PM}_{2.5}$ samples were collected from four functional regions in Chengdu, China, during 2010 and 2011. The changes of the concentrations of PM and their major constituents were analysed to evaluate the effects of pollution control strategies. The following can be concluded. The strategy of banning high-emission yellowtag vehicles was the most important reason for the TC reduction. The reduction of $\mathrm{SO}_{2}$ and $\mathrm{NO}_{\mathrm{x}}$ emissions played a key role in the decrease of sulphate and nitrate. The reduction of crustal dust may be attributed from the meteorological factor (long-range transport). Finally, FCA was employed to analyze the changes of possible source categories for the different years. The results showed that for commercial and residential regions, vehicle emissions may have been the important source in 2010, while their influence may have been relatively weaker in 2011; and for industrial and background regions, the dominant source categories may not have changed.

\section{ACKNOWLEDGMENTS}

This study is supported by Natural Science Foundation of China (21207070, 41205089, 41375132), Special Funds for Research on Public Welfares of the Ministry of Environmental Protection of China (201409003), and the Combined Laboratory of the Tianjin Meteorological Bureau and Nankai University.

\section{SUPPLEMENTARY MATERIALS}

Supplementary data associated with this article can be found in the online version at http://www.aaqr.org.

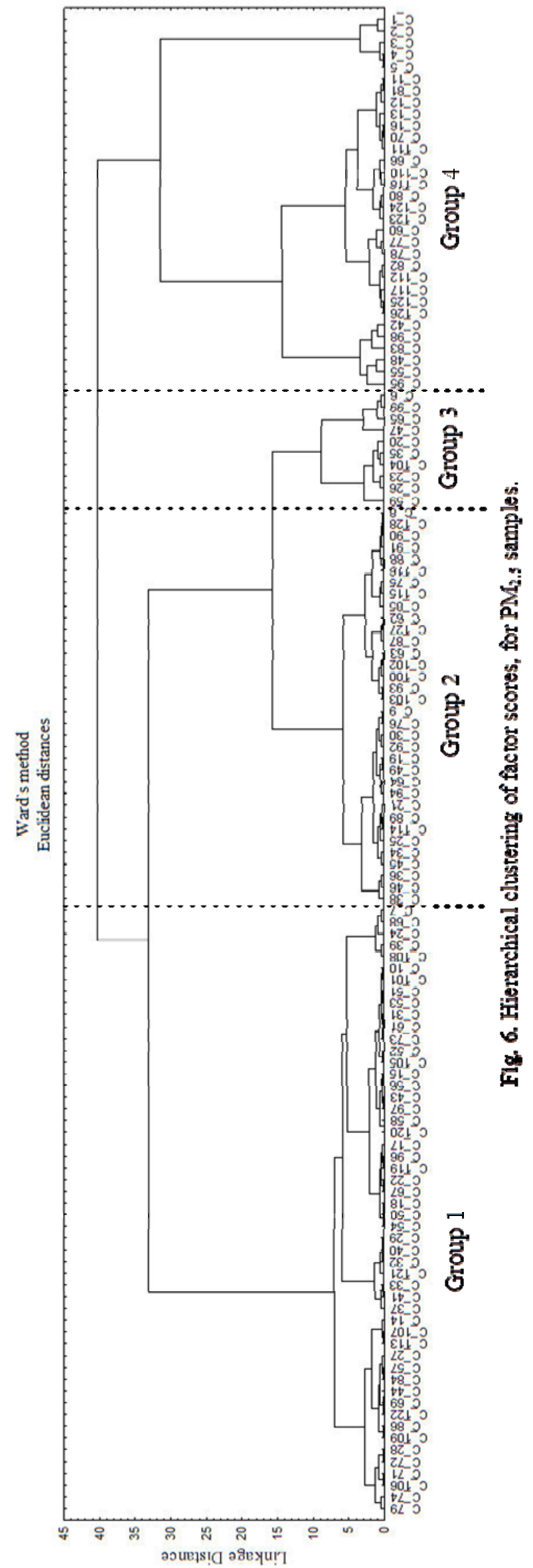




\section{REFERNENCES}

Amato, F. and Hopke, P.K. (2012). Source Apportionment of the Ambient $\mathrm{PM}_{2.5}$ across St. Louis Using Constrained Positive Matrix Factorization. Atmos. Environ. 46: 329337.

Andrews, E., Saxena, P., Musarra, S., Hildemann, L.M., Koutrakis, P., Mcmurry, P.H., Olmez, I. and White, W.H. (2000). Concentration and Composition of Atmospheric Aerosols from the 1995 Seavs Experiment and a Review of the Closure between Chemical Sandgravimetric Measurements. J. Air Waste Manage. Assoc. 50: 648664.

Baldwin, D.P., Zamzow, D.S. and D'Silva, A.P. (1994). Aerosol Mass Measurement and Solution Standard Additions for Quantization in Laser Ablation-Inductively Coupled Plasma Atomic Emission Spectrometry. Anal. Chem. 66: 1911-1917.

Begum, B.A., Biswas, S.K., Markwitz, A. and Hopke, P.K. (2010). Identification of Sources of Fine and Coarse Particulate Matter in Dhaka, Bangladesh. Air Aerosol Qual. Res. 10: 345-353.

Bellouin, N., Boucher, O., Haywood, J. and Reddy, M.S. (2005). Global Estimate of Aerosol Direct Radiative Forcing from Satellite Measurements. Nature 438: 11381141.

Bi, X.H., Feng, Y.C., Wu, J.H. and Wang, Y.Q. (2007). Source Apportionment of $\mathrm{PM}_{10}$ in Six Cities of Northern China. Atmos. Environ. 41: 903-912.

Cheng, Y.H., Chang, H.P. and Yan, J.W. (2012). Temporal Variations in Airborne Particulate Matter Levels at an Indoor Bus Terminal and Exposure Implications for Terminal Workers. Air Aerosol Qual. Res. 12: 30-38.

Chow, J.C., Watson, J.G., Pritchett, L.C., Pierson, W.R., Frazier, C.A. and Purcell, R.G. (1993). The DRI Thermal/Optical Reflectance carbon analysis system: Description, evaluation and applications in U.S. air quality studies. Atmos. Environ. 27A: 1185-1201.

Ehrlich, C., Noll, G., Kalkoff, W.D., Baumbach, G. and Dreiseidler, A. (2007). $\mathrm{PM}_{10}, \mathrm{PM}_{2.5}$, and $\mathrm{PM}_{1.0}-$ Emissions, from Industrial Plants-Results from Measurement Programmes in Germany. Atmos. Environ. 44: 6236-6254.

Escrig, A., Monfort, E., Celades, I., Querol, X., Amato, F., Minguillón, M.C. and Hopke, P.K. (2009). Application of Optimally Scaled Target Factor Analysis for Assessing Source Contribution of Ambient $\mathrm{PM}_{10}$. J. Air Waste Manage. Assoc. 59: 1296-1307.

Gianini, M.F.D., Gehrig, R., Fischer, A., Ulrich, A., Wichser, A. and Hueglin, C. (2012). Chemical Composition of $\mathrm{PM}_{10}$ in Switzerland: An Analysis for 2008/2009 and Changes Since 1998/1999. Atmos. Environ. 54: 97-106.

Harrison, R.M. and Yin, J. (2000). Particulate Matter in the Atmosphere: Which Particle Properties are Important for Its Effects on Health? Sci. Total Environ. 249: 85-101.

He, K., Yang, F., Ma, Y., Zhang, Q., Yao, X., Chan, C.K., Cadle, S., Chan, T. and Mulawa, P. (2001). The Characteristics of $\mathrm{PM}_{2.5}$ in Beijing, China. Atmos. Environ. 35: 4959-4970.

Hedberg, E., Gidhagen, L. and Johanson, C. (2005). Source
Contributions to $\mathrm{PM}_{10}$ Andarsenic Concentrations in Central Chile Using Positive Matrix Factorization. Atmos. Environ. 39: 549-561.

Heinberg, R. and Fridley D. (2010). The End of Cheap Coal. Nature 468: 367-369.

Ho, K.F., Lee, S.C., Cao, J.J., Chow, J.C., Watson, J.G. and Chan, C.K. (2006). Seasonal Variations and Mass Closure Analysis of Particulate Matter in Hong Kong. Sci. Total Environ. 355: 276-287.

Hwang, I. and Hopke, P.K. (2007). Estimation of Source Apportionment and Potential Source Locations of $\mathrm{PM}_{2.5}$ at a West Coastal IMPROVE Site. Atmos. Environ. 41: 506-518.

Li, X.R., Wang, L.L., Wang, Y.S., Wen, T.X., Yang, Y.J., Zhao, Y.A. and Wang, Y.F. (2012). Chemical Composition and Size Distribution of Airborne Particulate Matters in Beijing during the 2008 Olympics. Atmos. Environ. 50: 278-286.

Lim, J.M., Lee, J.H., Moon, J.H. and Chung, Y.S. (2010). Source Apportionment of $\mathrm{PM}_{10}$ at a Small Industrial Area Using Positive Matrix Factorization. Atmos. Res. 95: 88-100.

Lin, P., Huang, X.F., He, L.Y. and Yu, J.Z. (2010). Abundance and Size Distribution of HULIS in Ambient Aerosols at a Rural Site in South China. J. Aerosol Sci. 41: 74-87.

Masiol, M., Rampazzo, G., Ceccato, D., Squizzato, S. and Pavoni, B. (2010). Characterization of $\mathrm{PM}_{10}$ Sources in a Coastal Area near Venice (Italy): An Application of Factor-cluster Analysis. Chemosphere 80: 771-778.

Masiol, M., Squizzato, S., Ceccato, D., Rampazzo, G. and Pavoni, B. (2012). A Chemometric Approach to Determine Local and Regional Sources of $\mathrm{PM}_{10}$ and Its Geochemical Composition in a Coastal Area. Atmos. Environ. 54: 127-133.

Minguillon, M.C., Shembari, A., Triguero-Mas, M., de Nazelle, A., Dadvand, P., Figueras, F., Salvado, J.A., Grimalt, J.O., Nieuwenhuijsen, M. and Querol, X. (2012). Source Apportionment of Indoor, Outdoor and Personal $\mathrm{PM}_{2.5}$ Exposure of Pregnant Women in Barcelona, Spain. Atmos. Environ. 59: 426-436.

Moorhouse, S. (2007). US Air Pollution is Harmful and Fine Particles Can Kill. Nature 445: 709-709.

Morishita, M., Keeler, G.J., Kamal, A.S., Wagner, J.G., Harkema, J.R., and Rohr, A.C. (2011). Identification of Ambient $\mathrm{PM}_{2.5}$ Sources and Analysis of Pollution Episodes in Detroit, Michigan Using Highly Time-resolved Measurements. Atmos. Environ. 45: 1627-1637.

Murillo, J.H., Ramos, A.C., García, F.Á., Jiménez, S.B., Cárdenas, B. and Mizohata, A. (2012). Chemical Composition of $\mathrm{PM}_{2.5}$ Particles in Salamanca, Guanajuato Mexico: Source Apportionment with Receptor Models. Atmos. Res. 107: 31-41.

Niyobuhungiro, R.V. and Blottnitz, H.V. (2013). Investigation of Arsenic Airborne in Particulate Matter around Caterers' Wood Fires in the Cape Town Region. Air Aerosol Qual. Res. 13: 219-224.

Oh, M.S., Lee, T.J. and Kim, D.S. (2011). Quantitative Source Apportionment of Size-segregated Particulate 
Matter at Urbanized Local Site in Korea. Air Aerosol Qual. Res. 11: 247-264.

O'Ryan, R.E. (1996). Cost-Effective Policies to Improve Urban Air Quality in Santiago, Chile. J. Environ. Manage. 31: 302-313.

Pant, P. and Harrison, R.M. (2012). Critical Review of Receptor Modelling for Particulate Matter: A Case Study of India. Atmos. Environ. 49: 1-12.

Park, S.S. and Kim, Y.J. (2005). Source Contributions to Fine Particulate Matter in an Urban Atmosphere. Chemosphere 59: 217-226.

Querol, X., Alastuey, A., Moreno, T., Viana, M.M., Castillo, S., Pey, J., Rodríguez, S., Artiñano, B., Salvador, P., Sánchez, M., Garcia Dos Santos, S., Herce Garraleta, M.D., Fernandez-Patier, R., Moreno-Grau, S., Negral, L., Minguillón, M.C., Monfort, E., Sanz, M.J., PalomoMarín, R., Pinilla-Gil, E., Cuevas, E., de la Rosa, J. and Sánchez de la Campa, A. (2008). Spatial and Temporal Variations in Airborne Particulate Matter $\left(\mathrm{PM}_{10}\right.$ and $\mathrm{PM}_{2.5}$ ) across Spain 1999-2005. Atmos. Environ. 42: 3964-3979.

Shao, M., Wang, B., Lu, S., Yuan, B. and Wang, M. (2011). Effect of Beijing Olympics Control Measures on Reducing Reactive Hydrocarbon Species. Environ. Sci. Technol. 45: 514-519.

Shi, G.L., Li, X., Feng, Y.C., Wang, Y.Q., Wu, J.H., Li, J. and Zhu, T. (2009). Combined Source Apportionment, Using Positive Matrix Factorization-Chemical Mass Balance and Principal Component Analysis/Multiplelinear Regression-Chemical Mass Balance Models. Atmos. Environ. 43: 2929-2937.

Shi, G.L., Zeng, F., Li, X., Feng, Y.C., Wang, Y.Q., Liu, G.X. and Zhu, T. (2011). Estimated Contributions and Uncertainties of PCA/MLR-CMB Results: Source Apportionment for Synthetic and Ambient Datasets. Atmos. Environ. 45: 2811-2819.

Shi, G.L., Tian, Y.Z., Han, S.Q., Zhang, Y.F., Li, X., Feng, Y.C., Wu, J.H. and Zhu, T. (2012) Vertical Characteristics of Carbonaceous Species and Their Source Contributions in a Chinese Mega City. Atmos. Environ. 60: 358-365.

Shon, Z.H., Kim, K.H., Song, S.K., Jung, K., Kim., N.J. and Lee, J.B. (2012). Relationship between Watersoluble Ions in $\mathrm{PM}_{2.5}$ and Their Precursor Gases in Seoul Megacity. Atmos. Environ. 59: 540-550.

Tahir, N.M., Suratman S., Fong, F.T., Hamzah, M.S. and Latif, M.T. (2013). Temporal Distribution and Chemical Characterization of Atmospheric Particulate Matter in the Eastern Coast of Peninsular Malaysia. Air Aerosol Qual. Res. 13: 584-595.

Thurston, G.D., Ito, K. and Lall, R. (2011). A Source Apportionment of U.S. Fine Particulate Matter Air Pollution. Atmos. Environ. 45: 3924-3936.

Tian, Y.Z., Xiao, Z.M., Han, B., Shi, G.L., Wang, W., Hao, H.Z., Li, X., Feng, Y.C. and Zhu, T. (2013). Seasonal Study of Primary and Secondary Sources of Carbonaceous Species in $\mathrm{PM}_{10}$ from Five Northern Chinese Cities. Air Aerosol Qual. Res. 13: 148-161.

Tian, Y.Z., Wu, J.H., Shi, G.L., Wu, J.Y., Zhang, Y.F., Zhou, L.D., Zhang, P. and Feng, Y.C. (2013). Long-term Variation of the Levels, Compositions and Sources of Size-resolved Particulate Matter in a Megacity in China. Sci. Total Environ. 463-464: 462-468.

Tie, X., Wu, D. and Brasseur, G. (2009). Lung Cancer Mortality and Exposure to Atmospheric Aerosol Particles in Guangzhou, China. Atmos. Environ. 43: 2375-2377.

Tiwari, S., Chate, D.M., Pragya, P., Ali, K. and Bisht, D.S. (2012). Variations in Mass of the $\mathrm{PM}_{10}, \mathrm{PM}_{2.5}$ and $\mathrm{PM}_{1}$ during the Monsoon and the Winter at New Delhi. Air Aerosol Qual. Res. 12: 20-29.

Vernile, P., Tutino, M., Bari, G., Amodio, M., Spagnuolo, M., Gennaro, G.D. and Lillo, E.D. (2013). Particulate Matter Toxicity Evaluation Using Bioindicators and Comet Assay. Air Aerosol Qual. Res. 13: 172-178.

Wang, G.H., Wang, H., Yu, Y.J., Gao, S.X., Feng, J.F., Gao, S.T. and Wang, L.S. (2003). Chemical Characterization of Water-soluble Components of $\mathrm{PM}_{10}$ and $\mathrm{PM}_{2.5}$ Atmospheric Aerosols in Five Locations of Nanjing, China. Atmos. Environ. 37: 2893-2902.

Wang, S.X. and Hao, J.M. (2012). Air Quality Management in China: Issues, Challenges, and Options. J. Environ. Sci. 24: 2-13.

Wang, W., Primbs, T., Tao, S. and Simonich, S.L.M. (2009a). Atmospheric Particulate Matter Pollution during the 2008 Beijing Olympics. Environ. Sci. Technol. 43: 5314-5320.

Wang, Z.S., Wu, T., Shi, G.L., Fu, X., Tian, Y.Z., Feng, Y.C., Wu, X.F., Wu, G., Bai, Z.P. and Zhang, W.J. (2012). Potential Source Analysis for $\mathrm{PM}_{10}$ and $\mathrm{PM}_{2.5}$ in Autumn in a Northern City in China. Air Aerosol Qual. Res. 12: 39-48.

Watson, J.G., Chow, J.C., Lowenthal, D.H., Pritchett, L.C., Frazier, C.A., Neuroth, G.R. and Robbins, R. (1994). Differences in the Carbon Composition of Source Profiles for Diesel- and Gasoline-powered Vehicles. Atmos. Environ. 28: 2493-2505.

Wongphatarakul, V., Friedlander, S.K. and Pinto, J.P. (1998). A Comparative Study of $\mathrm{PM}_{2.5}$ Ambient Aerosol Chemical 614 Databases. Environ. Sci. Technol. 32: 3926-3934.

Wu, L., Feng, Y.C., Wu, J.H., Zhu, T., Bi, X.H., Han, B., Yang, W.H. and Yang, Z.Q. (2009). Secondary Organic Carbon Quantification and Source Apportionment of $\mathrm{PM}_{10}$ in Kaifeng, China. J. Environ. Sci.-China 21: 13531362.

Xu, L.L., Chen, X.Q., Chen, J.S., Zhang, F.W., He, C., Du, K. and Wang, Y. (2012). Characterization of $\mathrm{PM}_{10}$ Atmospheric Aerosol at Urban and Urban Background Sites in Fuzhou city, China. Environ. Sci. Pollut. Res. Int. 19: 1443-1453.

Zeng, F., Shi, G.L., Li, X., Feng, Y.C., Bi, X.H., Wu, J.H. and Xue, Y.H. (2010). Application of a Combined Model to Study the Source Apportionment of $\mathrm{PM}_{10}$ in Taiyuan, China. Air Aerosol Qual. Res. 10: 177-184.

Zhang, Z. and Friedlander, S.K. (2000). A Comparative Study of Chemical Databases for Fine Particle Chinese Aerosols. Environ. Sci. Technol. 34: 4687-4697.

Zhao, C., Tie, X.X. and Lin, Y.P. (2006). Reduction of Precipitation and Increase in Aerosols; a Positive 
Feedback in Eastern-Central China. Geophys. Res. Lett. 33: L11814.

Zheng, M., Salmon, L.G., Schauer, J.J., Zeng, L., Kiang, C.S., Zhang, Y. and Cass, G.R. (2005). Seasonal Trends in $\mathrm{PM}_{2.5}$ Source Contributions in Beijing, China. Atmos.
Environ. 39: 3967-3976.

Received for review, April 2, 2013 Accepted, September 23, 2013 


\title{
Supplementary Materials
}

\section{Evaluation of the Changes of the Concentration, Composition and Possible Sources of Size-Resolved Particulate Matter between 2010 and 2011 in a Western Chinese Mega City}

\author{
Yu-Fen Zhang ${ }^{1}$, Hong $\mathrm{Xu}^{1}$, Gui-Rong Liu ${ }^{1}$, Ying-Ze Tian ${ }^{1}$, \\ Guo-Liang Shi ${ }^{*}$, Jian-Hui Wu ${ }^{1}$, Pu Zhang ${ }^{2}$, \\ Lai-Dong Zhou ${ }^{2}$, Yin-Chang Feng ${ }^{1 * *}$
}

\footnotetext{
${ }^{1}$ State Environmental Protection Key Laboratory of Urban Ambient Air Particulate Matter Pollution Prevention and Control, College of Environmental Science and Engineering, Nankai University, Tianjin, 300071, China

${ }^{b}$ Chengdu Research Academy of Environmental Sciences, Chengdu 610041, China
}

\footnotetext{
${ }^{*}$ Corresponding author. Tel: +86 22 23503397; Fax: +86 2223503397

${ }^{* *}$ Corresponding author. Tel: +862223507962

E-mail addresses: nksgl@hotmail.com (Guo-Liang Shi); fengyc@nankai.edu.cn (Yin-Chang Feng).
} 
Table S1. PM and chemical species in other cities.

\begin{tabular}{|c|c|c|c|c|}
\hline City & PM & $\mu \mathrm{g} / \mathrm{m}^{3}$ & Period & Reference \\
\hline Chengdu & $\mathrm{PM}_{10}$ & $279.39 \pm 99.95$ & 2010 & This study \\
\hline Chengdu & $\mathrm{PM}_{10}$ & $200.62 \pm 69.18$ & 2011 & This study \\
\hline Taiyuan & $\mathrm{PM}_{10}$ & $305.46 \pm 192.17$ & $2001-2002$ & Zeng et al. (2010) \\
\hline Nanjing & $\mathrm{PM}_{10}$ & $316.20 \pm 162.12$ & 2001 & Wang et al. (2003) \\
\hline Fuzhou $^{\mathrm{a}}$ & $\mathrm{PM}_{10}$ & $69.92 \pm 30.10$ & 2008 Winter & Xu et al. (2012) \\
\hline Hong Kong ${ }^{\mathrm{b}}$ & $\mathrm{PM}_{10}$ & $55.75 \pm 23.84$ & 2000-2001 Winter & Ho et al. (2006) \\
\hline Korea & $\mathrm{PM}_{10}$ & $81.0 \pm 41.0$ & 2002 & Lim et al. (2010) \\
\hline Spain $^{\mathrm{c}}$ & $\mathrm{PM}_{10}$ & 50 & 1999-2005 & Querol et al. (2008) \\
\hline Switzerland $^{\mathrm{d}}$ & $\mathrm{PM}_{10}$ & 29.4 & $2008-2009$ & Giannini et al. (2012) \\
\hline Chengdu & $\mathrm{PM}_{2.5}$ & $178.75 \pm 80.52$ & 2010 & This Study \\
\hline Chengdu & $\mathrm{PM}_{2.5}$ & $134.62 \pm 46.09$ & 2011 & This Study \\
\hline Nan Jing & $\mathrm{PM}_{2.5}$ & $222.20 \pm 103.56$ & 2001 & Wang et al. (2003) \\
\hline Beijing $^{\mathrm{e}}$ & $\mathrm{PM}_{2.5}$ & 175.9 & 1999-2000 & He et al. (2001) \\
\hline Seoul & $\mathrm{PM}_{2.5}$ & $41.8 \pm 3.30$ & 1998-1999 & Park et al. (2005) \\
\hline Hong Kong & $\mathrm{PM}_{2.5}$ & $42.59 \pm 21.03$ & 2000-2001 Winter & Ho et al. (2006) \\
\hline Spain $^{c}$ & $\mathrm{PM}_{2.5}$ & 35 & 1999-2005 & Querol et al. (2008) \\
\hline US & $\mathrm{PM}_{2.5}$ & $14.2 \pm 0.2$ & $2000-2005$ & Thurston et al. (2011) \\
\hline
\end{tabular}

${ }^{\mathrm{a}}$ Urban - Ziyang site.

${ }^{\mathrm{b}} \mathrm{KT}$ site.

c Traffic - L'Hospital site.

${ }^{\mathrm{d}}$ Bern site.

${ }^{\mathrm{e}}$ Chegongzhuang site. 
Table S2. Average concentration ratio between $\mathrm{PM}_{2.5}$ and $\mathrm{PM}_{10}$.

\begin{tabular}{ccccc|cccc}
\hline & \multicolumn{5}{c}{$2010 \mathrm{PM}_{2.5} / \mathrm{PM}_{10}$} & \multicolumn{4}{c}{$2011 \mathrm{PM}_{2.5} / \mathrm{PM}_{10}$} \\
& Background & Commercial & Residential & Industrial & Background & Commercial & Residential & Industrial \\
\hline Mass conc. & 0.72 & 0.59 & 0.63 & 0.64 & 0.80 & 0.58 & 0.62 & 0.73 \\
$\mathrm{Na}$ & 0.44 & 0.30 & 0.29 & 0.34 & 0.52 & 0.34 & 0.34 & 0.38 \\
$\mathrm{Mg}$ & 0.50 & 0.15 & 0.36 & 0.38 & 0.53 & 0.27 & 0.40 & 0.45 \\
$\mathrm{Al}$ & 0.40 & 0.48 & 0.42 & 0.40 & 0.45 & 0.48 & 0.47 & 0.46 \\
$\mathrm{Si}$ & 0.47 & 0.35 & 0.49 & 0.40 & 0.55 & 0.34 & 0.49 & 0.56 \\
$\mathrm{~K}$ & 0.51 & 0.45 & 0.51 & 0.52 & 0.53 & 0.63 & 0.58 & 0.89 \\
$\mathrm{Ca}$ & 0.24 & 0.19 & 0.37 & 0.25 & 0.32 & 0.20 & 0.50 & 0.30 \\
$\mathrm{Ti}$ & 0.44 & 0.45 & 0.45 & 0.41 & 0.31 & 0.43 & 0.53 & 0.34 \\
$\mathrm{~V}$ & 0.70 & 0.69 & 0.67 & 0.64 & 0.89 & 0.57 & 0.62 & 0.78 \\
$\mathrm{Cr}$ & 0.73 & 0.35 & 0.57 & 3.72 & 0.95 & 0.64 & 0.63 & 0.50 \\
$\mathrm{Mn}$ & 0.65 & 0.55 & 1.24 & 0.62 & 0.76 & 0.89 & 0.59 & 0.73 \\
$\mathrm{Fe}$ & 0.50 & 0.32 & 0.35 & 0.32 & 0.51 & 0.31 & 0.35 & 0.47 \\
$\mathrm{Co}$ & 0.48 & 0.46 & 0.43 & 0.40 & 0.69 & 0.74 & 0.38 & 0.31 \\
$\mathrm{Ni}$ & 0.80 & 0.68 & 0.82 & 0.80 & 0.59 & 0.67 & 0.60 & 0.44 \\
$\mathrm{Cu}$ & 0.64 & 0.74 & 0.42 & 0.39 & 0.46 & 0.63 & 0.48 & 0.52 \\
$\mathrm{Zn}$ & 0.82 & 0.95 & 0.66 & 0.95 & 0.79 & 0.80 & 0.71 & 0.91 \\
$\mathrm{As}$ & 0.74 & 0.47 & 0.72 & 0.51 & 0.48 & 0.69 & 0.66 & 0.82 \\
$\mathrm{Cd}$ & 0.66 & 0.61 & 0.81 & 0.59 & 0.81 & 0.73 & 0.67 & 0.56 \\
$\mathrm{Hg}$ & 0.44 & 0.31 & 0.55 & 0.66 & 0.41 & 0.43 & 0.74 & 0.42 \\
$\mathrm{~Pb}$ & 0.85 & 0.70 & 0.91 & 0.74 & 0.84 & 0.67 & 0.74 & 0.44 \\
$\mathrm{TC}$ & 0.90 & 0.80 & 0.91 & 0.87 & 0.92 & 0.82 & 0.97 & 0.94 \\
$\mathrm{NO}{ }_{3}^{-}$ & 0.91 & 0.74 & 0.88 & 0.76 & 0.94 & 0.63 & 0.72 & 0.67 \\
$\mathrm{SO}{ }_{4}^{2-}$ & 0.87 & 0.79 & 0.67 & 0.61 & 0.91 & 0.66 & 0.72 & 0.70 \\
\hline
\end{tabular}


Table S3. The related reported data for Chengdu, in 2009 and 2010.

\begin{tabular}{|c|c|c|c|}
\hline & 2009 & 2010 & $\begin{array}{l}\text { Relative change } \\
\qquad(\%)\end{array}$ \\
\hline $\begin{array}{c}\text { Population } \\
\text { (million) }\end{array}$ & 11.4 & 11.5 & 0.88 \\
\hline $\begin{array}{l}\text { Annual total industrial coal consumption } \\
\text { (thousand tons) }\end{array}$ & 8690 & 7957 & -8.43 \\
\hline $\begin{array}{c}\text { Annual total industrial } \mathrm{SO}_{2} \text { emission } \\
\text { (thousand tons) }\end{array}$ & 127 & 96.8 & -23.78 \\
\hline $\begin{array}{l}\text { Annual total industrial } \mathrm{NO}_{\mathrm{x}} \text { emission } \\
\text { (thousand tons) }\end{array}$ & 57.8 & 52.4 & -9.34 \\
\hline $\begin{array}{c}\text { Vehicle population } \\
\text { (million) }\end{array}$ & 2.36 & 2.59 & 9.75 \\
\hline
\end{tabular}

The reported data was referred to the Chengdu Statistical Yearbook 2009, 2010.

The relative change $(\%)$ was calculated according to:

[Relative change] $=([2010]-[2009]) /[2009] \times 100$

where, [2010] is the data in 2010 and [2009] is the data in 2009

\section{References}

Bureau of Statistics of Chengdu. Chengdu Satistical Yearbook, 2009, 2010 (in Chinese).

Environmental Monitoring Center of Chengdu). Chengdu Environmental Quality Reports, 2006-2010 (in Chinese). 
Table S4. The pollution control strategies.

\begin{tabular}{lll}
\hline & \multicolumn{1}{c}{ Strategies } & \multicolumn{1}{c}{ time } \\
\hline Strategy 1 & Continuing reduction of $\mathrm{SO}_{2}$ emission & Target: 10\% every year \\
Strategy 2 & Yellow-tag vehicles banned from the & High-emission yellow-tag \\
& road & vehicles have been banned \\
& & from roads (from 7:30 to \\
& & $19: 30)$ in urban areas since \\
& & 1 Oct. 2010 \\
Strategy 3 & Other pollution control strategies & Forbidding the lawless \\
& & industrial emission; \\
& & Updating the outdated \\
& & environmental protection \\
& & technology in factories \\
\hline
\end{tabular}




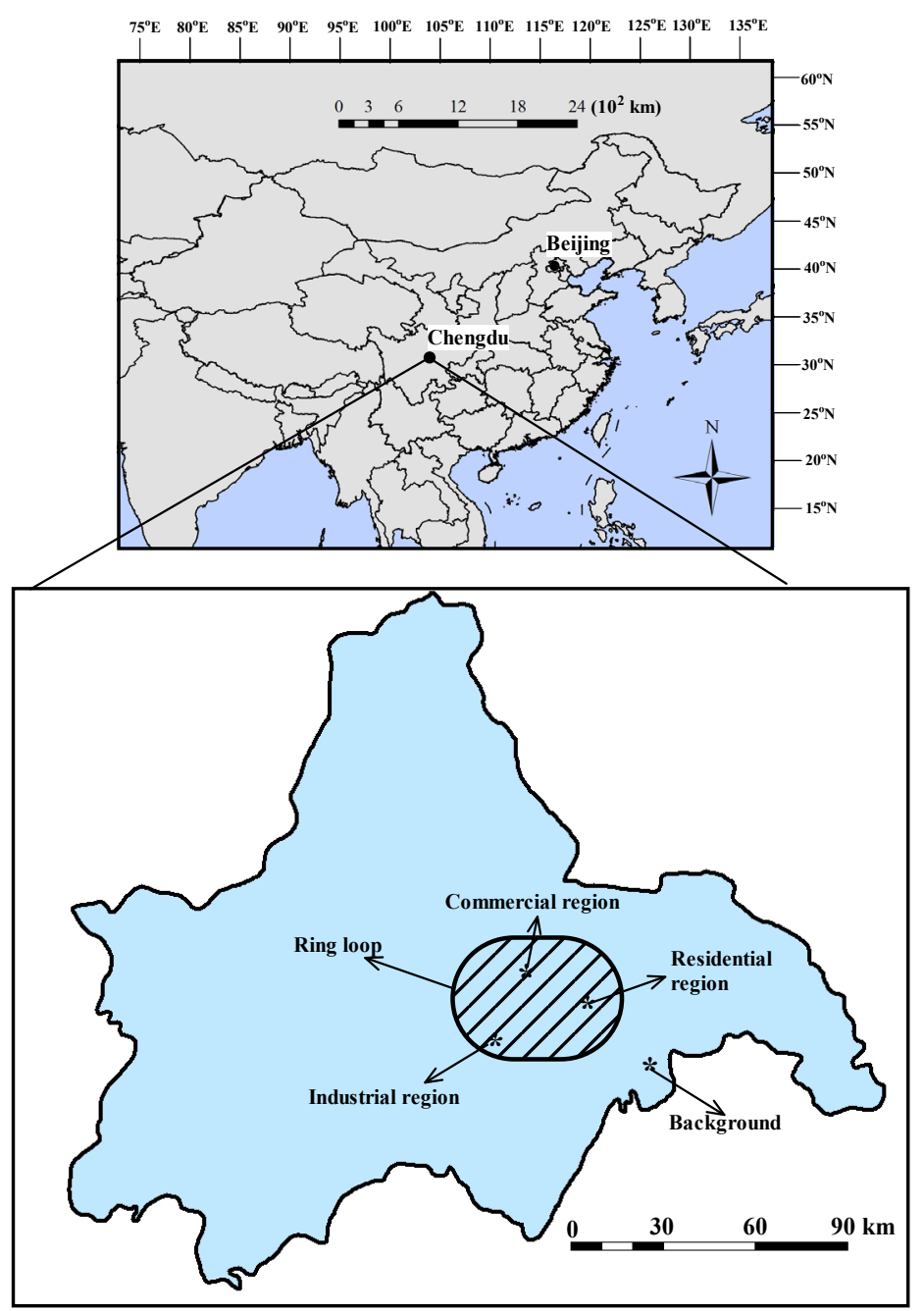

Fig. S1. Map of monitoring areas.

\section{Annotate:}

BaiGongYan (BGY: Background): 30³4'N, 104²17'E;

HuanBaoDaLou (HBDL: Commercial): 30³9'N, 104º2'E;

KeJiYuan (KJY: Industrial): $30^{\circ} 37^{\prime} \mathrm{N}, 104^{\circ} 03^{\prime} \mathrm{E}$;

SanWaYao (SWY: Residential): $30^{\circ} 36^{\prime} \mathrm{N}, 104^{\circ} 04^{\prime} \mathrm{E}$. 

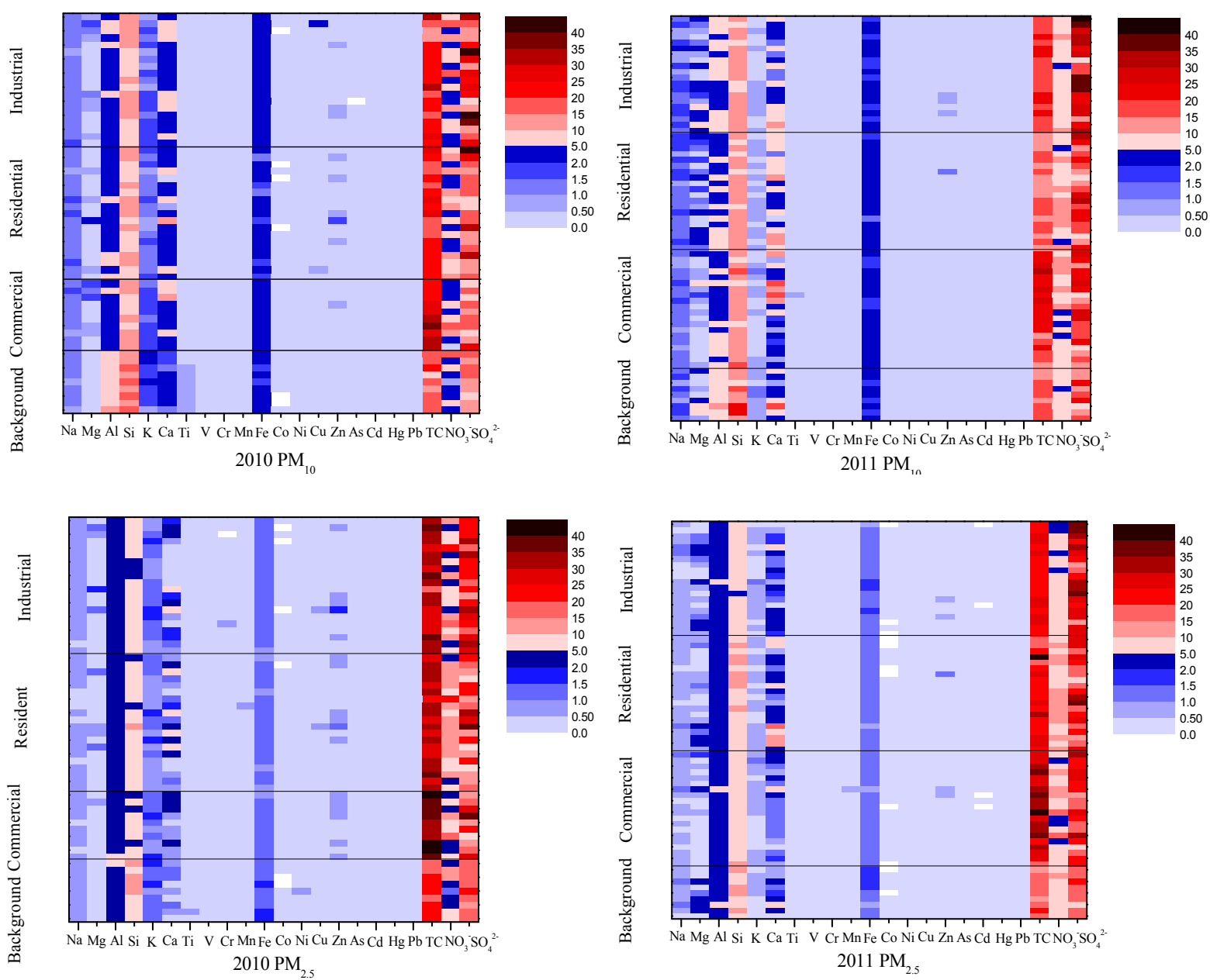

Fig. S2. Fractions (\%) of chemical species in size resolved PM from different regions, in 2010 and 2011. 


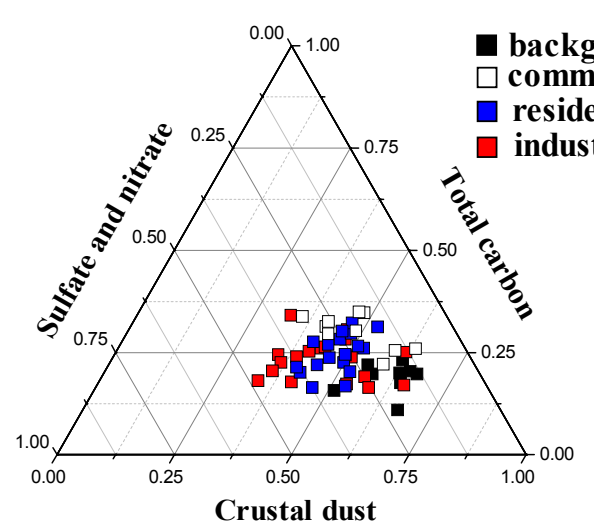

2010

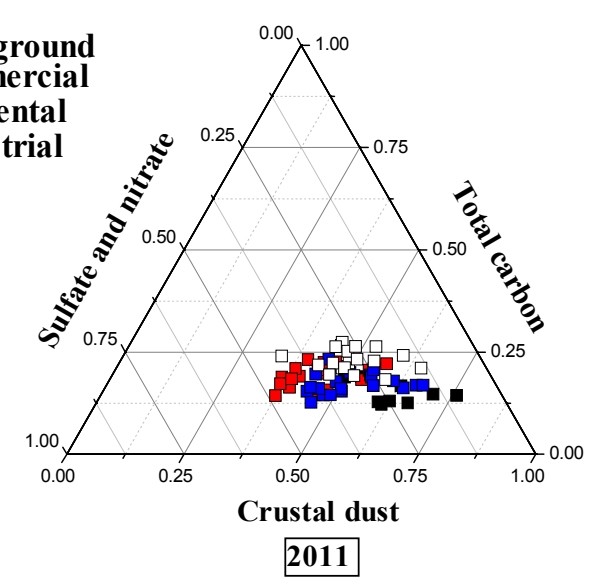

Fig. S3(a). Ternary plots for the fractions of crustal dust, TC and sulfate + nitrate in $\mathrm{PM}_{10}$ from different regions.

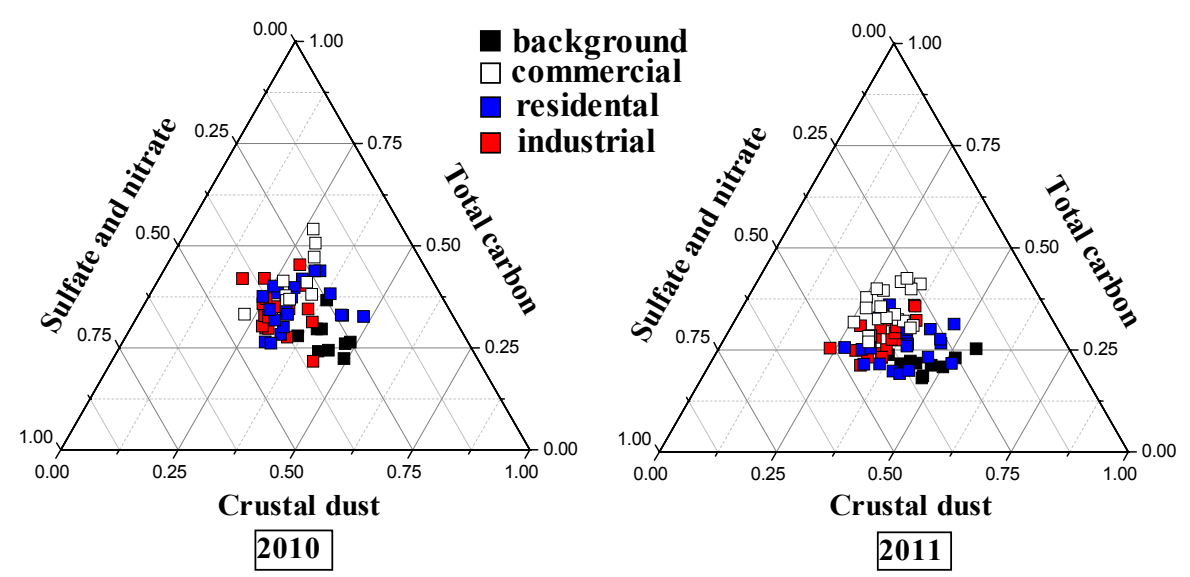

Fig. S3(b). Ternary plots for the fractions of crustal dust, TC and sulfate + nitrate in $\mathrm{PM}_{2.5}$ from different regions 


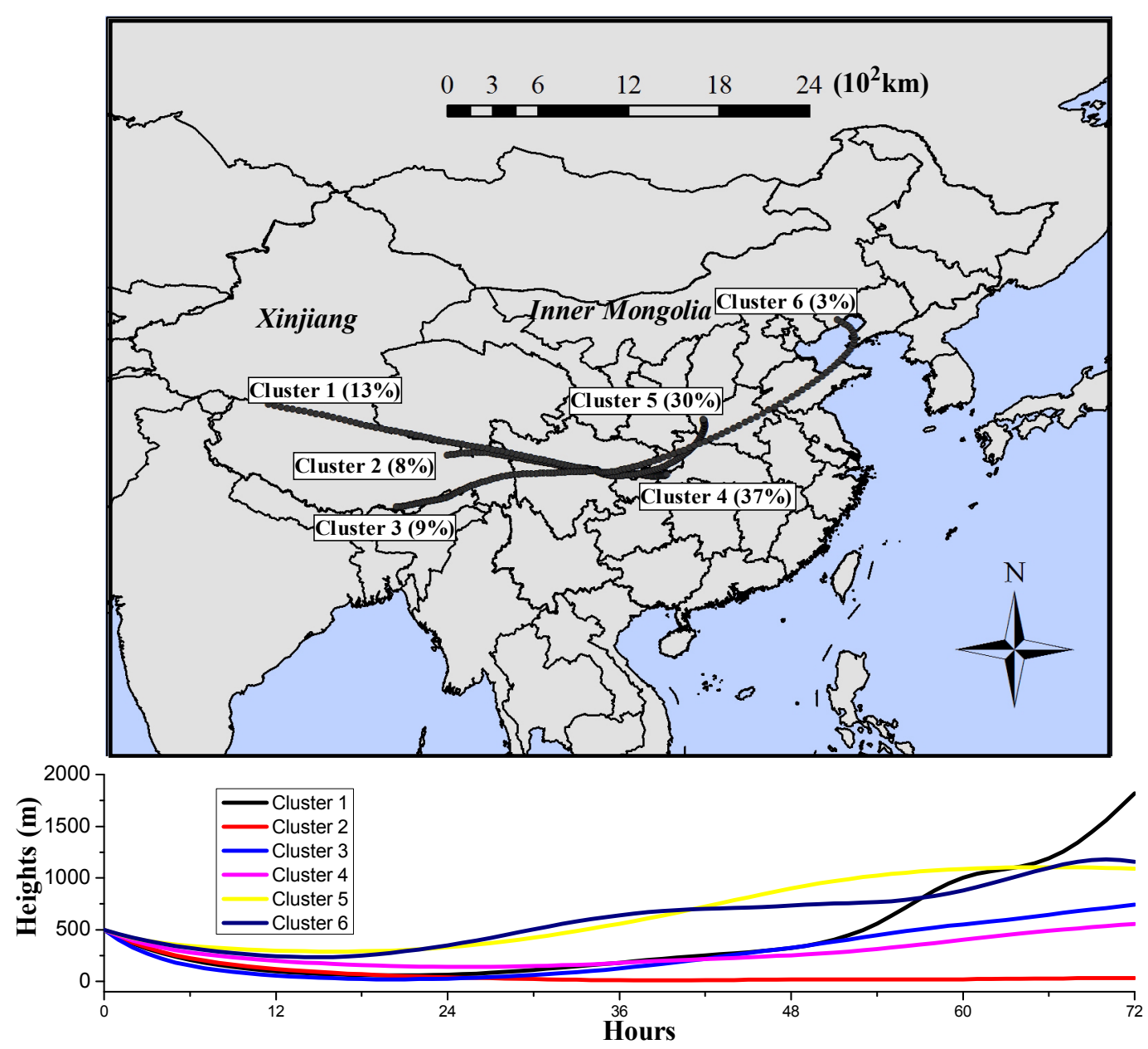

Fig. S4(a). 3D 72-h back trajectories cluster maps from 1 Jan. to 28 Feb. 2010 for Chengdu. 


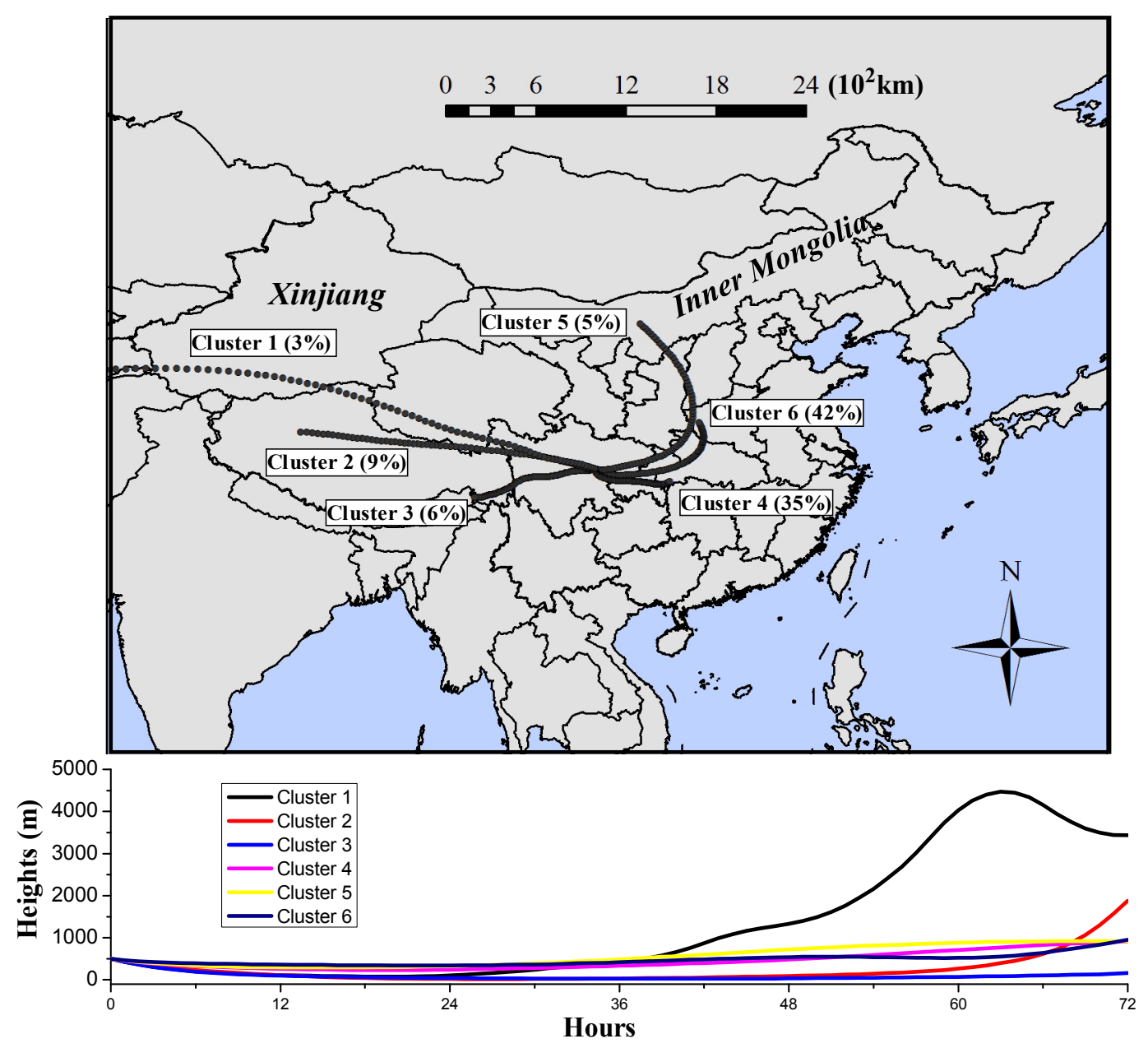

Fig. S4(b). 3D 72-h back trajectories cluster maps from 1 Jan. to 28 Feb. 2011 for Chengdu 